Sebastian Szajner

https://doi.org/10.18778/8220-636-4.02

\title{
FESTIWAL DIALOGU CZTERECH KULTUR (FD4K)
}

Festiwal Dialogu Czterech Kultur powstał z myślą o powrocie do kulturowych początków dziewiętnastowiecznej Łodzi i przywróceniu świadomości jej specyfiki wynikającej z wielonarodowego charakteru. Przywróceniu tej świadomości nie tylko lokalnej społeczności, ale także całej Polsce, ba - nawet całemu światu. Idea, która przyświecała temu przedsięwzięciu, polegała na symbolicznym połączeniu - za pośrednictwem sztuki - kultur, które przyczyniły się do stworzenia miasta: polskiej, żydowskiej, niemieckiej i rosyjskiej. Celem miał stać się gest wydobycia z (nie)pamięci unikalnego industrialnego organizmu, jaki stanowi Łódź, uzmysłowienie rodowodu i dynamiki tworzenia się miasta - tak niezwykłego w skali całej Europy. Tym samym Festiwal wpisywał się w proces budowania nowej marki i nowego wizerunku Łodzi. Wizerunku bardzo atrakcyjnego po latach identyfikowania miasta z metropolią robotniczą - ideologicznie „czerwoną”, a estetycznie „szarą”.

Oczywiście wyobrażenie współczesnej Łodzi jako miasta, dla którego wieloetniczność, różnorodność kulturowa i religijna, harmonijne współistnienie czterech nacji, jest naturalnym sposobem myślenia o sobie, to wyraz mitologizacji. To efekt budowania projektu tożsamościowego, który nie ma żadnego bezpośredniego odniesienia do dzisiejszej realnej sytuacji kulturowej. Niemniej, nie da się zaprzeczyć, że miasto powstałe $\mathrm{w}$ tyglu kultur, czerpiące $\mathrm{z}$ ich zjednoczenia energię i potrafiące tę energię spożytkować w praktyce, to wizja nie tylko pociągająca wizerunkowo, ale i uzasadniona historycznie. Architektem projektu Dialogu Czterech Kultur był Witold Knychalski - inicjator Towarzystwa na Rzecz Dialogu Kultur „Łódź - Ziemia Przyszłości” (2001 r.) - człowiek bardzo silnie zaangażowany w kulturalne i sportowe życie miasta. Urodził się w roku 1954 - nie w Łodzi, lecz w Chylinie, w Poznańskiem. Był absolwentem Wydziału Prawa na Uniwersytecie Łódzkim, ukończył aplikację sędziowską i adwokacką. W swoim aktywnym życiu zajmował wiele wysokich, opiniotwórczych stanowisk: był m.in. członkiem Krajowej Rady Radiofonii i Telewizji, zasiadał w zarządzie Spółki Akcyjnej RUCH, przewodniczył Radzie Nadzorczej Telewizji Polskiej, a także pełnił 
rolę doradcy w klubie piłkarskim ŁKS Łódź. Ale z nie mniejszą pasją oddawał się pracy społecznej. We wspomnieniach o Witoldzie Knychalskim nieodmiennie powraca fraza o ogromnych emocjach, jakie towarzyszyły społecznikowi przy tworzeniu wizji łódzkiego Festiwalu. FD4K wyrastał z nadziei, że za pomocą języka sztuki uda się połączyć, rozerwane przez czas i historię, więzy czterech kultur, dające niegdyś impuls do stworzenia Miasta.

Idea zrodziła się na wspomnienie dialogu, który w Łodzi toczył się nieprzerwanie przez wiele kolejnych dziesięcioleci. Ludzie czerpiący z czterech jakże odmiennych kultur, połączeni w tym dialogu budowali wspólnie fabryki, świątynie, kina, teatry i stadiony. Wspólnym wysiłkiem stworzyli największy pomnik porozumienia - Łódź, dynamicznie rozwijającą się i stwarzającą dla nich nadzieję na przyszłość. Dramatyczna historia minionego stulecia dialog przerwała. Holocaust Żydów, exodus Niemców i zupełna zmiana warunków historycznych wywarły na Łodzi ogromne piętno. Idea Festiwalu nawiązuje do pięknej tradycji Łodzi wspólnej wielu Narodom. Zmierza do odnowienia dialogu i zainspirowania dzieła kreacji. Chcemy aby pomógł on przywrócić dawną radość. Chcemy aby bal znów trwał! Dążymy do tego aby Festiwal stał się areną wypowiedzi. Żeby ludzie mieli szansę dyskutować w języku dającym ogromne możliwości wyrazu. Chcemy aby dialog ten toczył się w uniwersalnym języku sztuki. Tworząc Festiwal, myślimy o zbudowaniu nowej marki. Chcemy aby Festiwal stał się znakiem nie tylko Łodzi ale także Polski. Znakiem, który będzie rozpoznawany na całym świecie $[\ldots]^{1}$.

Obok ważnej lekcji historii, która była wpisana w założenia Festiwalu, zasadniczą rolę odgrywała $\mathrm{w}$ nim promocja miasta, wynikająca jednak $\mathrm{z}$ intencji znacznie ważniejszej niż cele marketingowe - redefinicji tożsamości Łodzi. Mimo iż sam FD4K zapamiętany został głównie przez pryzmat problemów finansowo-organizacyjnych i dość długo celebrowano jego klęskę, pisząc o nim, warto skupić się przede wszystkim na jego najważniejszej idei, czyli na utrwalaniu w świadomości odbiorców bogatej i dramatycznej historii Łodzi. A cel taki wydaje się szczególnie pożądany w czasach, w których nastroje nacjonalistyczne i ksenofobiczne stają się coraz silniejsze i powszechne. Opowieść o Łodzi, snuta w Łodzi, jest o tyle ważna, że mamy z nią tu do czynienia na każdym

1 Witold Knychalski, Idea Festiwalu Dialogu Czterech Kultur, cyt. za: Krzysztof Kowalewicz, Witold Knychalski nie żyje, „Gazeta Wyborcza - Łódź” (12 września 2006), http://lodz.wyborcza.pl/lodz/1,35153,3614013.html (dostęp: 28.11.2016). Tekst dostępny online pod hasłem 'Festiwal Dialogu Czterech Kultur' na stronie Wikipedii. Wolnej Encyklopedii: https://pl.wikipedia.org/wiki/Festiwal_Dialogu_Czterech_Kultur (dostęp: 30.11.2016). 
kroku, codziennie - „na ulicy”, jeśli tylko zdołamy wyostrzyć i uwrażliwić swoje spojrzenie. Nie jest to obraz zamknięty w muzealnych wystawach, opisany jedynie na papierze, bez żywej obecności minionego czasu. Choć tak długo i skutecznie tabuizowany, a w ostatnich latach także mitologizowany, obraz Łodzi ma szansę odzyskać swoją wyrazistość, gdy jego kreatorzy zwrócą się ku rzeczywistemu obliczu miasta, odrzucając jego stereotypowe wyobrażenia. Taką właśnie szansę, odzyskania niezafałszowanego wizerunku miasta, dawał Festiwal Dialogu Czterech Kultur.

By uzasadnić tę tezę, chciałbym - w największym skrócie - odwołać się do rytmu przemian tego specyficznego organizmu miejskiego, jaki stanowi Łódź ${ }^{2}$. Warto pamiętać, że początek przemysłowej Łodzi, czyli narodziny jej „wielkiej kariery” (jak to ujął Henryk Stanisław Dinter), to rok 1820, kiedy to namiestnik Królestwa Polskiego Józef Zajączek wyznaczył małą wówczas, rolniczą miejscowość na osadę włókienniczą. Dzięki planom rozwoju przemysłu podjętym przez władze Królestwa Polskiego Łódź zyskała nadzwyczajną szansę rozwoju. Pomysłodawcą industrialnego kursu miasta stał się jeden z jego pierwszych pasjonatów - Rajmund Rembieliński, który wystąpił o zezwolenie na urządzenie w Łodzi osady fabrycznej i utworzenie tu „fabryk sukiennych”3. $\mathrm{Z}$ powodu braku odpowiedniej liczby specjalistów na terenie Królestwa Polskiego przeprowadzono wielkie akcje propagandowe, aby zachęcić europejskich tkaczy i przędzalników do osadzania się w Łodzi. W ciągu ośmiu lat do miasta przybyło ponad tysiąc rodzin rękodzielników-włókniarzy oraz pierwsi prawdziwi przedsiębiorcy. Dzięki napływowi osadników liczba mieszkańców miasta do roku 1830 wzrosła ponad dziesięciokrotnie, a do początków lat 40 . już dwudziestosześciokrotnie. Łódź stała się wówczas miastem, które rozwijało się najszybciej nie tylko w Polsce, ale i w całej Europie 4 . Tę ogromną dynamikę rozwoju historycy porównują do fenomenu tzw. miast-grzybów w Stanach Zjednoczonych. Gwałtowny wzrost zamożności pierwszych niemieckich i żydowskich potentatów łódzkiego przemysłu tekstylnego powodował, że ich prywatną własnością stawały się ogromne tereny miasta, tworzące swoiste obszary

2 Korzystam tu z: Łódź. Dzieje Miasta. T. 1. Do 1918 r., red. Bohdan Baranowski, Jan Fijałek, Państwowe Wydawnictwo Naukowe, Warszawa-Łódź 1980; Henryk Stanisław Dinter, Dzieje wielkiej kariery. Łódź 1332-1860, Wydawnictwo Łódzkie, Łódź 1968; Marek Koter, Mariusz Kulesza, Wiesław Puś, Stefan Pytlas, Wptyw wielonarodowego dziedzictwa kulturowego Łodzi na wspótczesne oblicze miasta, Wydawnictwo Uniwersytetu Łódzkiego, Łódź 2005.

3 Za: Henryk Stanisław Dinter, Dzieje wielkiej ..., s. 83.

4 Julian Janczak, Ludność Łodzi przemystowej1820-1914, „Acta Universitatis Lodziensis. Folia Historica" 1982, t. 11, s. 38-40. 
funkcjonalno-urbanistyczne - „fabryki-twierdze”, „miasta w mieście” - które podporządkowywały życie mieszkańców trybowi pracy zakładu 5 .

Schyłek XIX stulecia przyniósł Łodzi intensywny rozwój przemysłu włókienniczego, co wiązało się z eskalacją napięć społecznych wynikających z trudnych warunków życia i pracy robotników. W roku 1892 wybuchł „bunt łódzki”; strajki doprowadziły do krwawo stłumionych starć z carskim wojskiem. Rewolucja roku 1905 - słynne „powstanie łódzkie”, o nie tylko społecznym, ale i antycarskim charakterze - wyprowadziła na ulice większość pracowników najemnych tego już nieomal półmilionowego ośrodka.

Pierwszy poważny łódzki kryzys, który zniszczył tkankę miasta i przyspieszył rytm przemian, był następstwem wybuchu I wojny światowej. W latach 1914-1918 nastąpiło wielkie wyludnienie Łodzi, spadek liczby mieszkańców sięgał blisko połowy populacji ${ }^{6}$. Powodem była agresywna polityka niemieckich władz okupacyjnych, które rozgrabiały łódzki przemysł, co doprowadziło do jego załamania. Obrazu klęski dopełniło odcięcie towarów tekstylnych od wschodnich rynków zbytu. W rezultacie takich procesów 250 tysięcy ludzi pozostało bez pracy. Pożoga wojenna i migracje ludności przyniosły nie tylko ogromny spadek liczebności łodzian, ale także wielkie zmiany w strukturze narodowościowej miasta. Przed wojną zdecydowaną część fabryk kontrolowali przedsiębiorcy i rzemieślnicy pochodzenia niemieckiego. Po wojnie proporcje między trzema największymi grupami etnicznymi zmieniły się zasadniczo: ludność niemiecka, która formowała przemysłowy rdzeń Łodzi i stanowiła na początku XX wieku blisko $40 \%$ jej mieszkańców, w latach dwudziestolecia międzywojennego obejmowała już tylko niecałe $9 \%$ populacji ${ }^{7}$.

Nie był to jednak koniec zawrotnego rytmu zmian, które kształtowaly oblicze miasta. Już w pierwszych latach niepodległości nastąpił kolejny spektakularny wzrost liczby mieszkańców: „W latach 1918-1939 liczba łodzian prawie się podwoiła" 8 . Tak żywiołowe przemiany demograficzne, a także administracyjne - miasto zostało stolicą województwa, a tym samym centrum oświaty i kultury - przyniosły też dynamiczny rozwój urbanistyczny. Łódź musiała

5 Jurydyka przemysłowa Karola Scheiblera zajmowała w latach 70. XIX wieku $1 / 7$ terytorium ówczesnej Łodzi, zob. Marek Koter, Rozwój przestrzenny i zabudowa miasta, [w: ] Łódź. Dzieje Miasta ..., s. 181.

6 Zob.: Wiesław Puś, Zmiany liczebności i struktury narodowościowej ludności Łodzi do roku 1939, [w:] Wplyw wielonarodowego dziedzictwa ..., s. 15.

7 Zob.: Marek Koter, Mariusz Kulesza, Ślady wielonarodowej i wielowyznaniowej Łodzi we wspótczesnym krajobrazie miasta, [w:] Marek Koter, Mariusz Kulesza, Wiesław Puś, Stefan Pytlas, Wplyw wielonarodowego ..., s. 138.

8 Wiesław Puś, Zmiany liczebności ..., s. 16. 
sprostać nowym, nieprzemysłowym funkcjom, wymagającym przekształcenia przestrzeni publicznej, zbudowania nowych obiektów administracji państwowej, kościelnej i wojskowej. Zmieniał się architektoniczny styl miasta. Prócz setek eklektycznych, neorenesansowych, klasycystycznych i secesyjnych budynków, Łódź zyskała też - mocno zmieniające jej pejzaż - nowoczesne obiekty, utrzymane w stylu modernistycznym ${ }^{9}$.

Dla refleksji nad charakterem FD4K najistotniejszy jest jednak inny rodzaj łódzkiej synergii: przed wybuchem II wojny światowej społeczeństwo żyło tu w znacznej koegzystencji. Wspólnymi siłami - co nie znaczy bezkolizyjnie - łodzianie tworzyli nie tylko przemysł włókienniczy, lecz także placówki związane z religią, kulturą i oświatą. Już w drugiej połowie XIX i u progu wieku XX wieku, prócz fabryk, banków, pałaców, kamienic i famul, powstawały w mieście świątynie i cmentarze różnych wyznań, a zaraz po nich: szkoły, teatry, kinematografy (to w Łodzi w 1899 r. otworzono pierwsze kino na ziemiach polskich!) oraz rozmaite instytucje służące rozrywce, kształceniu i wspólnemu spędzaniu wolnego czasu. Inicjowano działalność towarzystw teatralnych, stowarzyszeń śpiewaczych, bibliotek, dzienników i periodyków oraz wielu innych przedsięwzięć, potwierdzających charakter rodzącej się metropolii jako „Miasta Atrakcji” (określenie Łukasza Biskupskiego) ${ }^{10}$. Po wojnie takie zabiegi jeszcze się zintensyfikowały: w jednym miejscu pojawiały się wydarzenia i organizacje kreowane przez ludzi reprezentujących różne wyznania i narodowości oraz pozostające we wzajemnych zależnościach. Jeśli - co nieuniknione - ścierały się one bądź ze sobą rywalizowały, to jednak wszystkie nacje i kultury wspóltworzyły jeden krajobraz, z jego mieszanką smaków i stylów. Tak szeroka wspólnota definiowała mimowolnie nową jakość kształtującej się tu rzeczywistości kulturowej. Społeczności łączyły się w Łodzi nie tylko przez pragnienie zysku czy marzenie o osiągnięciu choćby względnej życiowej stabilności, ale również z potrzeby materializacji swoich potrzeb kulturalnych. To do tego potencjału wielokulturowości Łodzi nawiązywała idea FD4K.

II wojna światowa i czasy okupacji niemieckiej przyniosły Zagładę Żydów, śmierć i ucieczkę z miasta wielu tysięcy Polaków, migracje Niemców. Osobną, tragiczną historią są w latach 1940-1944 losy Litzmannstadt Ghetto, w którym stłoczono ponad 150 tysięcy Żydów z Łodzi, a kolejnych prawie 20 tysięcy

9 Zob.: Joanna Olenderek, Eódzki modernizm i inne nurty przedwojennego budownictwa, Księży Młyn Dom Wydawniczy, Łódź 2011.

10 Zob.: Łukasz Biskupski, Miasto Atrakcji. Narodziny kultury masowej na przełomie XIX i XX wieku. Kino w systemie rozrywkowym Łodzi, Narodowe Centrum Kultury, Szkoła Wyższa Psychologii Społecznej w Warszawie, Warszawa 2013, http:/ / otworzksiazke. pl/images/ksiazki/miasto_atrakcji/miasto_atrakcji.pdf (dostęp: 20.08.2016). 
przywieziono z Europy Zachodniej; umieszczono tu także ponad pięć tysięcy Romów i Sinti. Jak podają wszystkie źródła historyczne, przez Litzmannstadt Ghetto przeszło ponad 200 tysięcy ludzi, którzy wywożeni byli stąd do nazistowskiego ośrodka zgłady w Chełmnie nad Nerem (KL Kulmhof) ${ }^{11}$.

Powojenna Łódź, której substancja miejska w większości pozostała zachowana - choć, podobnie jak przemysł, ogromnie zdewastowana - jako największe niezrujnowane miasto $\mathrm{w}$ Polsce pełniła nieoficjalnie funkcję stolicy kraju. W ten sposób miasto stanowiło chwilową przystań dla ocalałej, lecz pozbawionej swoich siedzib inteligencji - przede wszystkim warszawskiej. Oprócz tego stawało się po raz kolejny Ziemią Obiecaną dla tysięcy robotników, którzy - zgodnie ze strategią socjalistycznej industrializacji - ściągali w poszukiwaniu pracy do znów dynamicznie się rozwijającego ośrodka. Jak pisze Małgorzata Leyko:

Przybysze zostawiali swoje ojcowizny pod Łowiczem, Kutnem czy Opocznem, dokąd wracali w porze żniw czy wykopków. W Łodzi z własną pamięcią o przeszłości wprowadzali się do zdewastowanych domów na Bałutach lub nowych bloków, które niczym teatralne kulisy zasłaniały przed wzrokiem miasta ruiny pogettowych zabudowań. Nie pytali o przeszłość tych miejsc, ale nikt też przez całe dziesięciolecia jej nie przypominal. Wszyscy patrzyli w przyszłość $^{12}$.

Tradycyjnie już w Łodzi impulsu miastotwórczego dostarczał przemysł włókienniczy ${ }^{13} \mathrm{i}$ to on spowodowal, że $\mathrm{w}$ ciągu pierwszych dwudziestu powojennych lat liczba łodzian znów zwiększyła się w dwójnasób. Reaktywowane fabryki zdecydowały o wzroście i rozwoju metropolii, a jednocześnie przesądzily o postrzeganiu jej w czasach PRL jako szarej siedziby „włókniarskiego ludu”. Aż do początków lat 90 . XX wieku, kiedy to wraz ze schyłkiem i likwidacją wielkich, nierentownych zakładów, a w konsekwencji gwałtownie rosnącym bezrobociem i wyludnianiem się Łodzi - miasto zaczęło upadać. Społeczne i ekonomiczne skutki transformacji ustrojowo-gospodarczej, w tym (kolejna w dziejach Łodzi)

11 Zob.: Paweł Spodenkiewicz, Zaginiona dzielnica. Łódź żydowska - ludzie i miejsca, Łódzka Księgarnia Niezależna, Łódź 1999; Julian Baranowski, Litzmannstadt Ghetto 1940-1944, [w: ] Żydzi łódzcy. Jews of Łódź, red. nauk. Andrzej Machejek, posł. Symcha Keller, tł. Dorota Dekiert i in., Wydawnictwo Hamal Andrzej Machejek, Łódź 2004, s. $85-101$.

12 Małgorzata Leyko, Miasto przygląda sięfestiwalom, [w: ] Między świętem a przesytem. Festiwale tetralne $i$ ich miejsce we wspótczesnym życiu kulturalnym Polski, red. Dariusz Kosiński, Teatr Lalek „Pleciuga”, Szczecin 2016.

13 Zob.: Jolanta Jakóbczyk-Gryszkiewicz, Łódź u progu XXI wieku, „Studia Miejskie” 2011, t. 4, s. 132. 
utrata wschodnich rynków zbytu, spowodowały głęboki kryzys w łódzkim przemyśle tekstylnym i odzieżowym, a ten pociągnął za sobą regres ośrodka.

$Z$ początkiem nowego wieku udało się jednak wskrzesić przemysłową tradycję miasta, choć w zupełnie innej odsłonie. Zgodnie z formułą opracowaną przez globalne firmy doradztwa strategicznego, zaczęły powstawać w Łodzi zakłady produkujące nowoczesny sprzęt AGD, a także centra zaplecza biznesowego i logistycznego ${ }^{14}$. Pęd codzienności skutecznie przysłania jednak przed wzrokiem współczesnych łodzian źródła mocy i przyczyny upadków ich miasta. Niewielu pamięta, że - jak sformułowali to artyści tworzący w czasie 8. FD4K projekt Anabasis: „Eódź $[\ldots]$ to w kontekście polskim miasto nieustannego przychodzenia i odchodzenia"15.

Dzieje FD4K są nie mniej burzliwe niż historia Łodzi, co bywa dziś (tylko na poły żartobliwie) interpretowane przez mieszkańców jako rodzaj festiwalowej klątwy. Taka klątwa dotknęła wcześniej istniejące tu przez kilka lat prestiżowe i pobudzające energię miasta wydarzenia: Paradę Wolności (1996-2002) i Międzynarodowy Festiwal Sztuki Autorów Zdjęć Filmowych „Camerimage” (2000-2009). Na temat losów FD4K, i jego kolejnych wcieleń, napisano dziesiątki interpretujących to wydarzenie artykułów, analiz kulturowych, notatek, spisów wydarzeń itp. Powstała także - obszerna i udokumentowana - praca Łukasza Biskupskiego i Tomasza Majewskiego: Festiwal Dialogu Czterech Kultur $w$ Łodzi - studium przy-(u)padku16, która zawiera (krytyczną) prezentację instytucji Festiwalu.

W tym miejscu chciałbym przypomnieć, że FD4K powstał w Łodzi w roku 2002 i w swojej pierwotnej formule, będącej przedmiotem tej refleksji, istniał do roku 2009 (osiem edycji). Do współpracy przy tworzeniu Festiwalu włączyli się ówcześni włodarze miasta, łódzcy artyści, a także lokalne środowisko naukowe. Trzeba podkreślić, że podjęcie idei wydarzenia, czyli także dekretowanie stanu wielokulturowości Łodzi, a nawet uznanie go za mit założycielski miasta, nie było zagadnieniem oczywistym. Wojna oraz wieloletnie działania komunistycznej propagandy głęboko przeorały świadomość i emocje mieszkańców „złego miasta”. Stworzenie wydarzenia, które odwoływałoby się do łódzkiego obyczaju

14 Ibidem, s. 134.

15 Marcin Grabowiecki, Wystawa „Anabasis. Rytuaty powrotu do domu” w Łodzi, https://www.fotopolis.pl/newsy-sprzetowe/wydarzenia/8546-wystawa-anabasis-rytualypowrotu-do-domu-w-odzi (dostęp: 15.08.2016).

16 Łukasz Biskupski, Tomasz Majewski, Festiwal Dialogu Czterech Kultur $w$ Łodzi - studium przy-(u)padku, „Kultura Współczesna” 2010, nr 4(66), s. 45-60, online: http: / / docplayer.pl/9433307-Festiwal-dialogu-czterech-kultur-w-lodzi-studium-przy-u-padku. html (dostęp: 20.11.2016). 
akceptacji i tolerancji Innych, wskrzeszało pamięć energii i żywotności wspólnotowych dokonań, było pomysłem atrakcyjnym wizerunkowo, lecz niezwykle trudnym do przeprowadzenia. Budowanie na tej podstawie genealogii i tożsamości miasta - wśród mieszkańców żyjących w nieomal monoetnicznej katolickiej społeczności - było wyłącznie projektem.

Powstaniu Festiwalu zdawał się jednak patronować duch prawdziwych lodzermenschów, których wyróżniała nie tylko pracowitość i wytrwałość, ale także pasja i przedsiębiorczość. Zgodnie z łódzką tradycją, aby urzeczywistnić projekt, próbowano zatem połączyć energię trzech kapitałów: ludzkiego, społecznego i finansowego. Ten ostatni, jak okazało się już wkrótce, nie spełnił jednak pokładanych w nim oczekiwań ${ }^{17}$.

FD4K miał być imprezą kulturalną zupełnie wyjątkową, budowaną z wielkim rozmachem, w nadziei stworzenia marki szeroko rozpoznawalnej tak w Polsce, jak i na całym świecie. Swoim symbolicznym związaniem z miejscem miał odwoływać się do najszacowniejszych wzorców - do funkcji Wawelu dla Krakowa czy Pałacu Kultury dla Warszawy ${ }^{18}$. Miał także być promotorem nowoczesnej, europejskiej wersji polskości oraz wizytówką prestiżu Łodzi, co sugerowały słowa Knychalskiego, witającego festiwalowych gości frazą: Jesteśz Polski?/ Z Polski, to tam, /gdzie odbywa się/ Festiwal Dialogu Czterech Kultur ${ }^{19}$. FD4K powinien również stać się nadzwyczajnym eventem, atrakcją turystyczną dla tysięcy gości, przynoszącą miastu niebagatelny dochód. Nie koniec na tym: miał także świadomie podejmować lokalne tradycje festiwalowe i eksponować przestrzeń miasta. Jak formułowali to inicjatorzy:

W założeniach przypomina Festiwal Teatralny „Ziemia Obiecana”, przemianowany później na Archipelag Ziemi Obiecanej, który w 1998 roku stworzył Zdzisław Hejduk, założyciel i wieloletni dyrektor Teatru 77. W zamyśle organizatorów wydarzenia artystyczne mają zagarniać całą przestrzeń miejską, odbywają się zatem nie

17 Zob.: Tomasz Patora, Marcin Stelmasiak, Festiwal Dialogu Czterech Kultur - kłopoty i co dalej?, „Gazeta Wyborcza - Łódź” (18 lipca 2003), https://wyborcza. pl/1,76842,1584034.html (dostęp: 26.11.2016).

18 Zob.: Waldemar Cudny, The Role of the Dialogue of Four Cultures Festival in Preserving the Multinational and Multicultural Heritage of Lodz, Centre for Tourism \& Cultural Change, Leeds Metropolitan University, 2007, online: https://www.academia. edu/10183397/Cudny_W_2007_The_Role_of_the_Dialogue_of_Four_Cultures Festival_in_Preserving_the _Multinational_and_Multicultural_Heritage_of_Lodz Conf. Proceedings Journeys of Expression_VI_Diaspora_Community_Festivals and Tourism Published by the Centre for Tourism and Cultural Change_Leeds_Metropolitan_University (dostęp: 28.11.2016).

19 Zob.: Tomasz Patora, Marcin Stelmasiak, Festiwal Dialogu... 
tylko w licznych instytucjach kultury, ale również w historycznych łódzkich wnętrzach, zapomnianych halach fabrycznych, na ulicach miasta 20 .

Tak zapowiadany pierwszy Festiwal rozpoczął się 27 września i trwał do 6 października 2002 roku. Wszystkie kolejne edycje Dialogu (do VIII Festiwalu w 2009 r.) zaczynały się nieco wcześniej: z początkiem września lub nawet pod koniec wakacji, w ostatnich dniach sierpnia. Zawsze obejmowały około dziesięciu dni, wypełnionych wielością zróżnicowanych gatunkowo pokazów. Organizacją imprezy w latach 2002-2007 zajmowało się - wspomniane już - Towarzystwo na Rzecz Dialogu Kultur „Ziemia Przyszłości”, kierowane przez Knychalskiego, przy współpracy Ryszarda Macieja Okuńskiego, który w latach 2003-2007 pełnił także funkcję dyrektora FD4K. Dyrektorem artystycznym I Festiwalu był natomiast Maciej Domański, były kierownik literacki teatrów, pracownik i doradca telewizji publicznej (współorganizatora imprezy).

W programie inicjowanego wydarzenia znalazło się aż „119 pozycji repertuarowych"21, reprezentujących, zgodnie z wolą pomysłodawców, różne dziedziny sztuki: teatr, operę, balet, muzykę, plastykę; film; kabaret; także wymianę myśli - aranżowano dyskusje panelowe i konferencje dotyczące zróżnicowanych obszarów dialogu międzykulturowego. Festiwal proponował publiczności także imprezy masowe, w tym entuzjastycznie przyjętą imprezę techno - Paradę Wolności Mega Party. Pierwszy FD4K rozpoczęły m.in.: musical Rock \& Troll Stanisława Tyma i Jerzego Derfla w Teatrze Lalki i Aktora „Pinokio” oraz wystawa pt. Mistrzowskie Trofea - Nagrody Andrzeja Wajdy 1958-2000 w Muzeum Kinematografii. Można powiedzieć, że w ten sposób narodziny Festiwalu symbolicznie przywoływały jego idee: wskrzeszenie tolerancji dla inności oraz odrodzenie mitu „ziemi obiecanej”. Sztuka Tyma - oparta na Podrzutku Selmy Lagerlöf - to baśń o potrzebie odrzucenia obawy i niechęci wobec obcych. W łódzkiej inscenizacji Waldemara Wilhelma powodowała, że nie można było zapomnieć o jej przesłaniu, „o upomnieniu się o prawo do inności drugiego człowieka"22. Natomiast pośrednie nawiązanie do mitu „ziemi obiecanej” i historii powstawania wielkiego miasta ujawniła wystawa Mistrzowskie Trofea,

20 Strona internetowa Festiwalu Dialogu Czterech Kultur. FD4K'09, http:// 2009.4kultury.pl/history/pl/site/festiwal-2002.html?edycja=171 (dostęp:28.11.2016).

21 Podsumowanie Festiwalu Dialogu Czterech Kultur, s. 4, http://2009.4kultury.pl/ UserFiles/fckeditor/file/2002/podsumowanie.pdf (dostęp: 15.11.2016).

22 Zob.: Leszek Karczewski, Song do przemyślenia, „Gazeta Wyborcza - Łódź” (15 września 2002), https://lodz.wyborcza.pl/lodz/7,35135,1017730.html (dostęp: 10.10.2016). 
prezentująca m.in. nominację do Oscara (1975) zdobytą przez Wajdę za Ziemię obiecana - najbardziej „łódzkie” dzieło światowej kinematografii.

Symboliczne znaczenie zyskiwał jednak przede wszystkim inauguracyjny Koncert Czterech Kultur, prezentujący cztery chóry: synagogalny - Jeruzalem Great Synagogue z kantorem Benzionem Millerem, katolicki - Polski Chór Chłopięcy z Poznania, prawosławny - Chór Patriarchatu Moskiewskiego Driewnierusskij Rasspiew Grindienki, i ewangelicki - Männer Stimmen der Evangelischen Knaben Chor - Ütersen.

O atrakcyjności I Dialogu przesądzały spektakularne wydarzenia, których ranga i skala przekraczały poziom zwyczajowo oglądanej w Łodzi produkcji artystycznej. Zaproszenie na FD4K przyjął jeden $\mathrm{z}$ najwybitniejszych twórców współczesnej sztuki tańca - Boris Ejfman, który właśnie w trakcie Festiwalu świętował rocznicę 25-lecia swojego zespołu. Sanktpetersburski Teatr Baletu Borisa Ejfmana pokazal Rosyjskiego Hamleta oraz jubileuszową Galę. Już następnego dnia łodzianie mogli wysłuchać koncertu słynnego kwartetu smyczkowego z San Francisco - Kronos Quartet, by w kolejnych dniach obejrzeć m.in.: inscenizację Króla Rogera Mariusza Trelińskiego lub spektakl Klaustrofobia Lwa Dodina z petersburskiego Małego Teatru Dramatycznego, albo wziąć udział w niezwykłej Podróży po Łódzkiej Ziemi Obiecanej, w którą - wiodąc uczestników przez zrujnowane hale dawnej fabryki Izraela Kalmanowicza Poznańskiego - zabrał widzów Zdzisław Hejduk i artyści Ośrodka Inicjatyw Artystycznych TEATR 77. Kolejnego dnia festiwalowa publiczność mogła uczestniczyć w monumentalnym plenerowym widowisku, kantacie scenicznej Carmina Burana, przygotowanej do muzyki Carla Orffa przez Art Concerts w Monachium. Niebiletowane przedstawienie prezentowane było w przestrzeni czteropoziomowej konstrukcji, ustawionej przed Teatrem Wielkim, a wziął w nim udział trzydziestoosobowy zespół taneczny, chór, soliści i orkiestra, których grę wzmacniały fascynujące efekty świetlne i pirotechniczne. Znane w całej Europie widowisko przywiodło na Plac Dąbrowskiego tłumy łodzian i stało się wielkim sukcesem Festiwalu.

Równolegle odbywały się prezentacje oper i musicali (Nabucco, Halka, Skrzypek na dachu, Big Popiel - „mysia opera” z muzyką Katarzyny Gärtner), spektakli plenerowych, koncertów muzyki klasycznej, jazzowej (m.in. włączony w program Dialogu - 4. Jazz Festival), rockowej, a także międzynarodowy Przegląd Zespołów Folkowych (a wśród nich np.: Hawana Club z Rosji, Fanaberie, Trebunie Tutki, Kapela ze wsi Warszawa czy... Łódź Kaliska). Inaugurowano cykle koncertów (np. Ballady i okolice), widowiska muzyczne z udziałem gwiazd teatru (Krystyna Janda, Marian Opania) i estrady (m.in.: Edyta Geppert, Katarzyna Groniec, Maciej Zembaty, Bettina Wegner, zespół Pod Budą, Wolna Grupa Bukowina, Grupa MoCarta, Justyna Steczkowska), ale także występy zespołów pop-rock (m.in. skandalizująca grupa Tatu, Budka Suflera, Varius Manx, Blue 
Café). Inny festiwalowy nurt stanowily wernisaże dzieł plastycznych. Pokazano prace wybitnych malarzy (m.in. Erny Rosenstein, Adama L. Doringa i Hansa P. Haufa), grafików, fotografików (m.in. wystawa Marlena Dietrich. Narodziny legendy ze zbiorów Deutsche Kinemathek Berlin), a na Piotrkowskiej ruszył Festiwal Instalacji Ulicznych. Jak przystało na Łódź, niezwykle rozbudowana była też sekwencja kinematograficzna Festiwalu. Zorganizowano przeglądy filmów TVP i ARTE oraz cykl: Przedwojenne Kino Żydowskie w Polsce (m.in. twórczość Aleksandra Forda, Józefa Greena czy Aleksandra Martena). Odbywały się prestiżowe premiery: Eden Andrzeja Czeczota, Moje pieczone kurczaki Iwony Siekierzyńskiej, Dziewice Jerzego Śladkowskiego. W ciągu kilku dni łodzianie mogli obejrzeć 67 filmów (fabularnych, dokumentalnych, animowanych, rejestrujących spektakle teatralne). Projekcje prezentowano zarówno na klasycznych ekranach, jak i przy użyciu technik multimedialnych.

Pierwszy FD4K zakończył wielki koncert Henryka Mikołaja Góreckiego z udziałem Narodowej Orkiestry Symfonicznej Polskiego Radia w Katowicach i chóru Filharmonii Narodowej pod dyrekcją Wojciecha Michniewskiego. Koncert połączony został z uhonorowaniem wielkiego kompozytora Nagrodą Tansmana, laurem innego tódzkiego festiwalu: Międzynarodowego Festiwalu i Konkursu Indywidualności Muzycznych im. Aleksandra Tansmana.

Pierwsza edycja interdyscyplinarnego Festiwalu Dialogu Czterech Kultur była szeroko komentowana $\mathrm{w}$ prasie, $\mathrm{w}$ radiu i w telewizji - nie tylko w Polsce, ale również za granicą. Był on wzmiankowany i opisywany w ponad dwustu artykułach, zaistniał we wszystkich polskich telewizjach oraz w mediach zagranicznych - w Rosji, w Niemczech, w Wielkiej Brytanii i w Izraelu. Towarzyszyła mu także okazjonalnie wydawana gazeta festiwalowa. Wydarzenie to zgromadziło około stu tysięcy widzów (!), co jest wyrazem niespotykanego zainteresowania polską imprezą kulturalną, a także dowodem wielkiego sukcesu wizerunkowego i medialnego otwierającego się Festiwalu ${ }^{23}$. Imprezy festiwalowe organizowano w wielu miejskich instytucjach kultury, a także w przestrzeni miasta - przede wszystkim przy ulicy Piotrkowskiej, gdzie karnawałowe święto sztuki pulsowało każdego dnia.

Niestety, wbrew oczekiwaniom, dokonania te nie przełożyły się na pomyślność finansową przedsięwzięcia. Ranga i liczba artystów zaproszonych do Łodzi, ale przede wszystkim wielość oferowanych w programie wydarzeń (nie zawsze w pełni uzasadnionych merytorycznie i potwierdzających spójność programową 1. FD4K) oraz kłopoty organizacyjne, pochłonęły ogromne koszty

23 Zob.: Waldemar Cudny, The Role..., s. 70; Anna Pawłowska, Eódź-miasto festiwali w zagrożeniu, „Dziennik Łódzki” (12 marca 2010), http://lodz.naszemiasto.pl/artykul/ lodz-miasto-festiwali-w-zagrozeniu,344808,art,t,id,tm.html (dostęp: 20.11.2016). 
i pociągnęły za sobą konieczność spłaty poważnego zadłużenia ( $4 \mathrm{mln}$ zł), jakie pierwsza edycja Festiwalu sprowadziła na jego organizatorów, co - finalnie - stało się jednym z powodów upadku Dialogu ${ }^{24}$. Niemniej impreza szybko urosła do rangi ważnego wydarzenia międzynarodowego i zaczęła pełnić rolę kulturowej wizytówki Łodzi.

Druga edycja Festiwalu odbyła się rok później i trwała od 14 do 20 września 2003 roku. Zmieniła się obsada kierowniczych stanowisk. Dyrektorem FD4K - w czasie kolejnych pięciu jego edycji - został Ryszard Maciej Okuński. Natomiast funkcję dyrektora artystycznego objął Michał Merczyński, który sprawował ją przez trzy lata. Zatrudnienie Merczyńskiego, świetnego animatora kultury, inicjatora i wieloletniego dyrektora jednego $\mathrm{z}$ największych polskich festiwali teatralnych - Międzynarodowego Festiwalu Teatralnego MALTA, zwiastowało dalsze umiędzynarodowienie i okrzepnięcie FD4K na mapie wydarzeń kulturalnych. Budżet Dialogu stopniał wprawdzie dramatycznie: z $10 \mathrm{mln}$ w roku poprzednim do 2,8 $\mathrm{mln}$ zł w drugiej edycji ${ }^{25}$, ale Merczyński należał do grona prawdziwych entuzjastów Festiwalu i podjął się niełatwego zadania. Jak mówił: „To projekt najbardziej ekscytujący, jeśli chodzi o polską kulturę w obliczu jednoczącej się Europy"26.

By zachować atrakcyjność festiwalowych propozycji, organizatorzy zdecydowali się na skonsolidowanie prezentowanych wydarzeń w szczególnej łódzkiej przestrzeni: w obszarze byłej jurydyki Poznańskiego - pierwotnie ogromnej fabryki tkackiej, która była jedną z największych w Europie. Na pofabrycznym terenie powstało „miasto namiotów” (muzyczny, teatralny, cyrkowy), dysponujące prawie trzema tysiącami miejsc dla publiczności. W osobnym namiocie urządzono studio telewizyjne, bowiem Festiwal miał być relacjonowany przez różne kanały telewizji publicznej. Trzeba przypomnieć, że znane dziś centrum handlowo-rozrywkowe Manufaktura zostało otwarte w tym miejscu dopiero trzy lata później. W czasie 2. FD4K był to kompleks opuszczonych budynków, których rewitalizacja zaledwie się zaczynała. „Te 27 hektarów w centrum miasta nie działało od trzynastu lat. Warto ożywić to miejsce" - twierdził Merczyński27.

Drugi Festiwal zainaugurowało niezwykłe wydarzenie - koncert The Israel Philharmonic Orchestra w Teatrze Wielkim, pod dyrekcją samego Zubina

24 Zob.: Łukasz Biskupski, Tomasz Majewski, Festiwal Dialogu ..., passim; Tomasz Patora, Marcin Stelmasiak, Festiwal Dialogu...

25 (kk) [Krzysztof Kowalewicz], Drugi Festiwal Dialogu Czterech Kultur, „Gazeta Wyborcza-Łódź”(9września 2003), https://lodz.wyborcza.pl/lodz/7,35135,1663587. html (dostęp: 23.11.2016).

26 Ibidem.

27 Ibidem. 
Mehty. Muzycy zachwycająco wykonali VII Symfonię e-moll Gustava Mahlera, dedykowaną przez nich pamięci wielkiego łodzianina - Artura Rubinsteina. Początek Dialogu stanowił jednocześnie jego kulminację. Tak z powodów artystycznych, jak i ze względu na głębokie związki łączące izraelskich muzyków z Polską, z Łodzią i - przede wszystkim - z ideą Festiwalu: „Większość zespołu stanowili muzycy wywodzący się z Polski, wielu z nich pochodziło z wielonarodowościowej, międzywojennej Łodzi"28.

Tak jak w poprzednim roku, widzowie mogli oglądać występy artystów z Polski, Rosji, Niemiec i Izraela, lecz repertuar festiwalowy był tym razem bez porównania skromniejszy, a jego sprofilowanie trudne do uchwycenia. Do zestawu tradycyjnych dyscyplin artystycznych dołączyła współczesna sztuka cyrku. Zaprezentowano dwie grupy: międzynarodową kompanię cyrku teatralnego Gosh - która przyjechała do Polski z Niemiec z widowiskiem Pelahueso, stanowiącym „teatralny esej o ich miłości do cyrku”29, a także sławną rosyjską grupę klaunów z Teatru Licedei, ze spektaklem Semianyki. Obie niezwykle się spodobały, bawiły publiczność pomysłowością i kunsztem gry artystów. Wyczekiwanym gościem festiwalowym był Teatr im. Heleny Modrzejewskiej z Legnicy. „Drużyna Modrzejewskiej” Jacka Głomba pokazała w Teatrze Muzycznym Zonę - spektakl w reżyserii Lecha Raczaka, zainspirowany Stalkerem Andrieja Tarkowskiego - oraz Wschody i Zachody Miasta Roberta Urbańskiego, wykreowaną scenicznie przez Głomba opowieść o teatrze i o Legnicy: mieście Niemców, Polaków, Żydów i Rosjan. Swoje propozycje dołączył do repertuaru II Dialogu Teatr im. Stefana Jaracza (Toksyny, Merylin Mongot), a specjalny program z muzyką rosyjską i żydowską przygotował Teatr Buffo. Wydarzeniem z kręgu sztuk plastycznych była oryginalna wystawa rzeźb Katarzyny Kobro: „Czterokrotnie powiększone repliki dwóch rzeźb, wykonane przez Tomasza Matuszaka i Zbigniewa Dudka z pracowni rzeźby łódzkiej Akademii Sztuk Pięknych [... ]"30 ustawione zostały na terenie „miasteczka festiwalowego”. Odbył się również przegląd twórczości izraelskich artystów video artu (pt.: Homemade). Były panele dyskusyjne - tym razem pod patronatem tygodnika „Polityka” - oraz koncerty (m.in. Stanisława Soyki). Przy niewątpliwej atrakcyjności wielu propozycji, tak wielkie zróżnicowanie festiwalowego repertuaru zaczęło jednak budzić niepokój odbiorców.

28 Strona internetowa Festiwalu Dialogu Czterech Kultur. FD4K'09, http://2009.4kultury.pl/history/pl/site/festiwal-2003.html (dostęp: 16.11.2016).

29 Leszek Karczewski, Gosh i Licedei, „Gazeta Wyborcza - Łódź” (17 września 2003), https://lodz.wyborcza.pl/lodz/7,35135,1676429.html (dostęp: 15.11.2016).

30 Strona internetowa Festiwalu Dialogu Czterech Kultur. FD4K'09, http:// 2009.4kultury.pl/history/pl/site/festiwal-2003.html (dostęp: 16.11.2016). 
Charakter trzeciej edycji Festiwalu określiła przypadająca na 29 sierpnia 2004 roku 60. rocznica likwidacji Litzmannstadt Ghetto. W czasie dziewięciu festiwalowych dni (3-11 września 2004) przedstawiono kilka ważnych wydarzeń artystycznych odnoszących się do tej tragicznej rocznicy. Otwierało III Festiwal unikalne plenerowe widowisko muzyczno-plastyczne pt. Niewidzialni, które Jerzy Kalina zrealizował wieczorem na Starym Rynku, na terenie byłego getta. Artysta zaprosił słynnego kantora z synagogi przy Piątej Alei w Nowym Jorku - Josepha Malovany'ego, jednego z najwybitniejszych współczesnych tenorów. Publiczność, szczelnie wypełniająca duży plac, w skupieniu słuchała śpiewu Malovany'ego towarzyszącego odtworzeniu dzieła symfonicznego Šma Israel (Sz'ma Izrael [Słuchaj Izraelu] na głos kantora, chóry chłopięcy i męski oraz orkiestrę symfoniczną) litewskiego kompozytora Anatolijusa Šenderovasa ${ }^{31}$. W Łodzi wykorzystane zostało wspaniałe nagranie zrealizowane przez Lithuanian National Symphony Orchestra (pod dyrekcją Robertasa Šervenikasa) i chór Ąžuoliukas (prowadzony przez Vytautasa Miškinisa) ${ }^{32}$.Żarliwość modlitewnego uniesienia kantora intonującego kadisz za zmarłych mieszkańców getta i ekspresję młodego dyrygenta - Łukasza Borowicza, „prowadzącego” dźwięk (nieobecnej na scenie) orkiestry, wspierał mistyczny efekt ognia płonących zniczy i żarzących się ognisk-macew. Nawet ulewny deszcz nie przerwał widowiska - jednego z najbardziej przejmujących w dziejach Festiwalu i najsilniej wpisujących się w jego idee. Malovany śpiewał, a publiczność z wielkim wzruszeniem słuchała jego pieśni, uzmysławiając sobie sens wykreowanej przez Kalinę rzeczywistości. Jak relacjonowała Magdalena Sasin:

Żywych wykonawców było tego wieczoru tylko dwóch: dyrygent Łukasz Borowicz i kantor Joseph Malovany. A nieżywych... o wiele więcej. To na nich czekały instrumenty, dla nich lampki oświetlały orkiestrowe pulpity z nutami, to zamiast nich w miejscu dla chórzystów stały rzędy kolumn [...]. Nie było wątpliwości, że Joseph Malovany naprawdę się modli, tutaj, na Starym Rynku, gdzie 60 lat temu decydowały się losy jego współbraci ${ }^{33}$.

W programie 3. FD4K znalazło się jeszcze kilka znakomitych propozycji, reprezentujących różne gatunki muzyki. Niewątpliwie takim był koncert poświęcony twórczości Gii Kanczelego, który odbył się w kościele

31 Zob. hasło 'Anatolijus Šenderovas', portal: Music Information Centre Lithuania, https://www.mic.lt/en/database/classical/composers/senderovas/ (dostęp: 20.11.2016);

32 Zob.: Magdalena Sasin, Niewidzialni na estradzie, „Gazeta Wyborcza - Łódź” (1 września 2004), https://lodz.wyborcza.pl/lodz/7,35135,2262555.html (dostęp: 18.11.2016).

33 Ibidem. 
ewangelicko-augsburskim św. Mateusza. Głęboko duchowe kompozycje gruzińskiego kompozytora - cztery modlitwy pod tytułem Life without Christmas - perfekcyjnie wykonane przez orkiestrę kameralną AUKSO pod dyrekcją Marka Mosia, uznane zostały przez wielu uczestników Festiwalu za jego artystyczną kulminację. Artyści i organizatorzy zadedykowali koncert pamięci ponad trzystu ofiar zamachu terrorystycznego przeprowadzonego 1 września 2004 roku na szkołę w Biesłanie.

Wśród prezentowanych w czasie 3. FD4K spektakli teatralnych także można było odnaleźć wybitne wydarzenia. Takim był Dybuk według Szymona An-skiego i Hanny Krall w reżyserii Krzysztofa Warlikowskiego z TR Warszawa. Zafrapowała widzów również niekonwencjonalna opowieść o Holokauście - Adam Resurrected, którą napisał Alexandr Chervinsky na podstawie powieści Yorama Kaniuka, a przedstawił dwujęzyczny, hebrajsko-rosyjski, Gesher Theatre z Izraela. Łódzkie sceny reprezentowały: Teatr Jaracza (pokazał premierę Wojny Matki, opracowaną na motywach Mutter Courage Bertolta Brechta przez Zdzisława Jaskułę i Remigiusza Brzyka - i przez niego wyreżyserowaną) oraz Teatr Powszechny (z musicalowym monodramem Dziś wieczorem: Lola Blau Georga Kreislera w reżyserii Andrzeja Ozgi, z Beatą Olgą Kowalską). Co istotne dla formuły Dialogu: obydwa spektakle były współprodukowane przez FD4K. Natomiast performerzy z Łodzi Kaliskiej, z właściwą sobie przekorą, problematyzowali dzisiejszy konsumpcjonizm, interpretując w nowym projekcie dzieło prekursora pop-artu Richarda Hamiltona: Just What Is It that Makes Today's Homes So Different, So Appealing? [Co właściwie sprawia, że dzisiejsze mieszkania są tak odmienne, tak pociągające?]. Sporym zainteresowaniem cieszyły się recitale znanych aktorek - Hanny Schygulli z Niemiec i Orny Porat z Izraela, jak również koncerty polskich artystek i artystów: Hanny Banaszak, Sławy Przybylskiej oraz Janusza Radka. Tłumnie publiczność stawiła się na zamykającym Festiwal Muzycznym Dialogu Czterech Kultur Krzesimira Dębskiego. Wielbiciele kinematografii obejrzeli w Filmówce cykl projekcji: Czterech wielkich, czterech kultur, obejmujący twórczość Volkera Schlöndorffa, Wojciecha Hasa, Andrieja Tarkowskiego i Romana Polańskiego. Natomiast wydarzenia plastyczne reprezentowane były tym razem nadzwyczaj skromnie: zaproponowano wernisaż prac niemieckiej malarki Kathariny Mann Wszystko zaczyna się $i$ kończy kobietą oraz wystawę fotografii w Bałuckim Domu Kultury.

Trzecia odsłona Festiwalu przyniosła też ważne zmiany organizacyjne: przygotowaniem imprezy zajęła się nowo powołana Fundacja Festiwalu Dialogu Czterech Kultur, zadeklarowano także silniejsze sprecyzowanie formy wydarzenia. Postanowiono w każdym z kolejnych festiwali prezentować trzy bloki programowe:

[...] program główny, czyli najważniejsza kompozycja projektów festiwalowych, prezentująca najciekawsze zjawiska artystyczne, również projekty zamawiane 
i koprodukowane przez festiwal; Łódź festiwal! - prezentacje wszystkich łódzkich środowisk, które utożsamiają się z ideą festiwalu i ukazują Łódź jako różnorodny tygiel artystyczny oraz blok imprez towarzyszących, czyli festiwalowe obrzeża, otwarte na zjawiska z pogranicza działań artystycznych ${ }^{34}$.

Trzeba przyznać, że III Dialog nosił już pewne cechy podobnego porządku. Szczególnie zwracała uwagę - zgodna z transformacją kategorii festiwalu we współczesnej kulturze - procedura aranżowania i współprodukowania przez FD4K konkretnych projektów. Przykład Niewidzialnych Kaliny dawał nadzieję na pozyskanie w ten sposób wydarzeń wyjątkowych i konsekwentnie wpisujących się w idee Festiwalu.

Czwarty Dialog - ostatni prowadzony artystycznie przez Merczyńskiego - oficjalnie i uroczyście zainaugurował 27 sierpnia w Filharmonii Koncert Muzyki Filmowej tegorocznego zdobywcy Oskara: Jana A.P. Kaczmarka. Artysta uhonorowany w roku 2005 za muzykę do filmu Marca Fostera Finding Neverland [Marzyciel], wprowadził ją do programu wieczoru, a obok niej zaprezentował swoje utwory z: Unfaithful [Niewierna] Adriana Lyne'a, Trzeciego Cudu Agnieszki Holland oraz z Quo Vadis Jerzego Kawalerowicza. Koncertowali muzycy Polskiej Orkiestry Radiowej pod dyrekcją Wojciecha Rajskiego, Chór Uniwersytetu Poznańskiego i soliści: irańska śpiewaczka Sussan Deyhim oraz Krzysztof Herdzin (fortepian) i Marta Maślanka-Stanisławska (cymbały).

Ze względu na obchodzony wŁodzi w 2005 roku Rok Krajów Obszaru Języka Niemieckiego i wynikające z tego zobowiązania, 4. FD4K rozpoczął się wcześniej niż zazwyczaj - już 26 sierpnia (na dzień przed oficjalną inauguracją) - i trwał do 4 września. Pogłębiające się trudności finansowe Festiwalu i znów niska dotacja 35 (jak na tak wielką i prestiżową imprezę) spowodowały, że Merczyński musiał zrezygnować z części planowanych w programie wydarzeń (choć i tak pozostało ich niemało, bo ponad 80), eksponując efektowne, ludyczne pokazy, często rozgrywające się w przestrzeni miasta. Tak właśnie rozpoczął się IV Dialog: od Zadymy na ulicy Piotrkowskiej, czyli radosnego pochodu z udziałem orkiestr dętych, pod wodzą artystów z poznańskiego Teatru Strefa Ciszy i berlińskiego Bängditos Theater. W trakcie korowodu Strefa Ciszy zapraszała łodzian do uczestniczenia w spektaklu Judasze. „W specjalnym kontenerze widzowie przez »judasze « mogli podglądać zainscenizowane przez artystów wesele. Artyści wciągali do zabawy

34 Strona internetowa Festiwalu Dialogu Czterech Kultur. FD4K'09, http:// 2009.4kultury.pl/history/pl/site/festiwal-2004.html?edycja=173 (dostęp: 19.11.2016).

35 Dotacja wynosiła 2,5 mln złotych, przy czym nieomal połowę - milion - przyznał na jego organizację ( $\mathrm{z}$ rezerwy budżetowej) ówczesny premier - Marek Belka, który był w 2005 roku honorowym patronem imprezy. 
przechodniów, których częstowali m.in. ogórkami i chlebem"36. Berliński teatr zaś pokazał uliczne widowisko Aniołowie Stróże. Korowodowi asystowała parada starych samochodów, reprezentujących „cztery kultury”: warszaw, syrenek, trabantów, mercedesów, czajek, wołg i ład. Karnawałowe święto zakończyło się wieczorem na Starym Rynku trzygodzinnym Piknikiem Orkiestr Dętych ${ }^{37}$.

Skoro 2005 rok ogłoszono w Łodzi Rokiem Krajów Obszaru Języka Niemieckiego, także 4. FD4K w szczególności eksponował różne obszary kultury niemieckiej. W programie (w którym wyraźnie dało się już wyróżnić: linię główną, cykl Łódź Festiwal! oraz imprezy towarzyszące) pojawily się m.in. dwie ważne niemieckie grupy teatralne: Rimini Protokoll i (niemiecko-brytyjska) Gob Squad. Obydwa teatry wywodzą się ze szkoły teorii i praktyki teatru zainicjowanej przez Andrzeja Wirtha w Instytucie Teatrologii Stosowanej w Giessen w latach 80. $\mathrm{XX}$ wieku; obydwa też reprezentują nurt współczesnego teatru interweniującego $\mathrm{w}$ przestrzeń społeczną, bliskiego teatrowi dokumentalnemu, w którym relacjonuje się i poddaje komentarzowi doświadczenia występujących na scenie osób (nieprofesjonalnych aktorów). Helgard Haug, Stefan Kaegi i Daniel Wetzel, czyli współtwórcy założonego w roku 2000 Rimini Protokoll, przyjechali do Łodzi ze stworzonym przez siebie w 2003 roku wstrząsającym spektaklem Deadline. Trzykrotnie pokazane na scenie Teatru Jaracza przedstawienie to, wedle słów jego twórców: „A play about death - not about bloodthirsty tyrants and jealous lovers, but about the average Central European death" [Spektakl o śmierci - nie o krwiożerczych tyranach i zazdrosnych kochankach, ale o przeciętnej środkowoeuropejskiej śmierci ${ }^{38}$. Zatem także o śmierci ujętej w kontekście procesu umierania i instytucji temu procesowi towarzyszących: nie tylko medycznych, lecz także wszystkich tych, które organizują odprawianie ciał, ceremonie pogrzebowe, decydują o strukturze cmentarzy, kształcie pomników - dla których śmierć jest elementem codziennego porządku i biznesu. Na łodzianach, mających w pamięci nekroaferę „towców skór” z lokalnego Pogotowia Ratunkowego - sprzed zaledwie trzech lat - spektakl wywarł ogromne wrażenie.

Brytyjsko-niemiecki zespół Gob Squad, który nazywa siebie „kolektywem” - dla podkreślenia w pełni demokratycznej i wolnościowej zasady swojej współpracy - powstał w roku 1994. To także teatr daleki od formuly tradycyjnego teatru

36 (KI) portal Onet.pl (26 sierpnia 2005), https://wiadomosci.onet.pl/zadyma-napiotrkowskiej-rozpoczela-4-festiwal-dialogu-czterech-kultur/c5tr0 (dostęp: 10.10.2016).

37 Katalog: Program Festiwalu Dialogu Czterech Kultur 2005, autorzy tekstów katalogu: Piotr Sarzyński, Małgorzata Warzecha, http://2009.4kultury.pl/UserFiles/ fckeditor/file/2005/ProgramFestiwalu2005_pl-en.pdf (dostęp: 16.10.2016).

38 Strona internetowa teatru Rimini Protocoll, https://www.rimini-protokoll.de/ website/en/project/deadline (dostęp: 16.11.2016). 
dramatycznego. Twórczość „kolektywu” łączy różne konwencje artystyczne i gatunki (teatr, performans, film, instalacja wideo) z formami codziennego, rzeczywistego życia. Spektakl Super Night Shot, trzykrotnie pokazany w Łódzkim Domu Kultury, stanowił świetny przykład metody pracy grupy. Intermedialne widowisko polegało na tym, że artyści odtwarzali sfilmowaną przez siebie, na godzinę przed odtworzeniem nagrania w sali ŁDK-u, wędrówkę czwórki spośród nich po ulicach miasta. Wędrówkę tę odbyli (w kostiumach), próbując zaradzić wszelkim problemom, jakie ujawniały się $\mathrm{w}$ kontaktach $\mathrm{z}$ przechodniami ${ }^{39}$. Podstawową rolę $\mathrm{w}$ tak kreowanych wydarzeniach odgrywa przypadek, nieprzewidywalność i niepowtarzalność chwili. Ich warunkiem jest poczucie wolności i świadomość ryzyka twórców. O ostatecznym kształcie sfilmowanego materiału - i całego widowiska - decyduje publiczność. Obydwa wydarzenia odrzucały tradycyjnie pojmowaną teatralność, problematyzowały granice rzeczywistości i fikcji, stanowiąc dla odbiorców wyzwanie i zapoznając ich jednocześnie z nowymi sposobami budowania performansów. I co - w kontekście rozwoju Festiwalu najważniejsze - włączały do jego przestrzeni (rzeczywistej i mentalnej) dzisiejszą Łódź, z jej obrazem, doświadczeniami, lękami i kompleksami.

Rzesze oddanej publiczności zgromadził także jeden z najsłynniejszych europejskich teatrów awangardowych - rosyjski (dziś emigracyjny) Teatr Derevo. Teatr powstał w roku 1988 w Sankt Petersburgu; założył go Anton Adassinsky [Adasiński]. Grupa, stacjonująca obecnie w Dreźnie, jest zespołem międzynarodowym, występującym na wielu światowych scenach i festiwalach. W Łodzi teatr pokazał spektakl La Divina Commedia, swobodnie nawiązujący do Boskiej Komedii Dantego i stanowiący ekspresyjną, infernalną wizję uniwersum. Przedstawienie zdobyło wiele nagród, w tym Fringe First i Total Theatre Award na Festiwalu w Edynburgu w roku 2002, toteż jego sprowadzenie do Łodzi było niewątpliwym sukcesem. Derevo w swoich bezsłownych widowiskach buduje nielinearne narracje i wyraża emocje za pomocą ekstatycznego tanecznego i pantomimicznego gestu i ruchu, łącząc różne techniki, m.in. contemporary dance, pantomimę, butō, komedię dell'arte, klaunadę. Spektakl zostal pokazany trzykrotnie w Łódzkim Centrum Filmowym i - mimo swojej estetycznej kontrowersyjności - zyskal uznanie widzów.

Pozostałe propozycje teatralne 4. D4K stanowiły produkcje łódzkich scen: Pinokia (Śladami Andersena), Jaracza (Graj, klezmerska kapelo), Nowego (Nadludzie), a także Śródmiejskiego Domu Kultury (Siostry Parry). Sekwencję teatralną - i jednocześnie cały Festiwal - zamknęło widowisko muzyczno-teatralne Kwiaty

39 Strona internetowa teatru Gob Squad, https://www.gobsquad.com/projects/ super-night-shot/ (dostęp: 19.11.2016). 
polskie, przygotowane przez legnicki Teatr Modrzejewskiej i wystawione na Starym Rynku.

Dla usposobionych tradycyjnie widzów Chór Teatru Wielkiego (prowadzony przez Marka Jaszczaka) i Orkiestra Symfoniczna TW (pod dyrekcją Tadeusza Kozłowskiego) przedstawiły widowisko Va, pensiero... Najpiękniejsze Chóry Świata. Spektakl, w którego tytule znalazły się pierwsze słowa pieśni żydowskich niewolników z III aktu Verdiowskiego Nabucco, składał się z najsłynniejszych utworów chóralnych i instrumentalnych światowego repertuaru operowego. Koncert został entuzjastycznie przyjęty przez publiczność zgromadzoną w Teatrze Wielkim i - powtórnie - na Starym Rynku.

Muzyka i śpiew stanowily bardzo mocny punkt programu IV Dialogu. Zwieńczeniem Festiwalu stał się koncert jednego z najwspanialszych skrzypków świata, łotewskiego artysty Gidona Kremera i jego orkiestry Kremerata Musica. Niezwykle prestiżowym i obleganym wydarzeniem był też ECM Festival, czyli prezentacja dokonań słynnej monachijskiej wytwórni Editions of Contemporary Music, specjalizującej się w jazzie i muzyce współczesnej. W programie imprezy, wchodzącej w skład IV Dialogu i zorganizowanej w kościele św. Mateusza, znalazły się koncerty: Tomasz Stańko Quartet (w wyśmienitym składzie: Tomasz Stańko - trąbka; Marcin Wasilewski - fortepian; Sławomir Kurkiewicz - kontrabas; Michał Miśkiewicz - perkusja); Valentina Silvestrova Requiem dla Larisy (utwór o cechach łacińskiego requiem, skomponowany po śmierci żony Larissy Bondarenko) w wykonaniu AUKSO - Orkiestry Kameralnej Miasta Tychy poprowadzonej przez Wojciecha Michniewskiego oraz koncert kompozytorski Arvo Pärta - Kanon Pokajanen w wykonaniu Estonian Philharmonic Chamber Choir, pod dyrekcją Tőnu Kaljuste. Słynny Kanon Pärta pojawił się w Łodzi w wykonaniu zgodnym z prapremierą dzieła z 17 marca 1998 roku w katedrze w Kolonii (utwór został stworzony na jubileusz 750-lecia świątyni). Wykonując dzieło a cappella (zgodnie z tradycją rosyjskiej muzyki sakralnej), śpiewacy Chóru Kameralnego siedzą/stoją w kręgu, zwróceni twarzami do siebie, a tyłem do publiczności. To przestrzenne wydzielenie chórzystów odbiera śpiewanym przez nich odom charakter popisu, przemieniając koncert w obrzęd, czego ze wzruszeniem doświadczyli uczestnicy lódzkiego festiwalu.

Oczekiwanym wydarzeniem był także występ izraelskiej wokalistki Noa, koncertującej w Filharmonii ze swoim zespołem - Noa Trio, w towarzystwie polskiego Rubinstein Quartet. Miłośnicy muzyki klubowej mogli uczestniczyć w cyklu imprez New Sounds of Germany z udziałem czołowych polskich i niemieckich DJ-ów. Muzyczny charakter miał także projekt artystów i muzealników z Krasnojarska, którzy na Piotrkowskiej przedstawili parateatralną akcję uliczną z udziałem syberyjskiego szamana, mistrza tzw. śpiewu gardłowego. Nie brakowało koncertów znanych artystów, świetny był m.in. występ Ewy Bem. 
Także wydarzenia plastyczne przyciągały tłumy: 500 osób pojawiło się w Atlasie Sztuki na wernisażu wystawy Argumenta, ze zbiorów Gerharda Jürgena Blum-Kwiatkowskiego, znanego polskiego artysty, kolekcjonera, teoretyka i twórcy „stanów wyjątkowych sztuki” 40 , założyciela m.in. Museum Modern Art Hünfeld. Właśnie z Hünfeld przywiezionych zostało do Łodzi około stu dzieł, reprezentujących prace z kręgu „sztuki geometrycznej” XX wieku. W innych lódzkich galeriach wystawy otworzyli m.in.: Konstantin Batinkow, Srul Werman, Ryszard Bilan i Avraham Eilat.

$\mathrm{Z}$ wielkim zainteresowaniem spotkała się wystawa fotografii i projekcja filmów Leni Riefenstahl, wspólpracującej z nazistami reżyserki perfekcyjnych filmów propagandowych hitlerowskich Niemiec, jednej z najbardziej kontrowersyjnych postaci światowego filmu. Tłumy zgromadzily zarówno pokazy filmów (m.in.: Triumph des Willens, 1934, Olympia, film o Igrzyskach Olimpijskich w Berlinie w 1936 r.), jak i spotkanie dyskusyjne poświęcone twórczości i postawie etycznej reżyserki (pt.: „Czy i co można wybaczyć Leni?”).

Publiczność dopisywała także podczas innych dyskusji i konferencji, organizowanych w ramach Forum „Polityki” w Instytucie Europejskim czy w Salonie Muzyczno-Literackim w Klubie JazzGa - jednym z najlepszych polskich pubów muzycznych. Popularnością cieszyły się wszystkie spośród 80 festiwalowych „eventów”: pokazy filmów, wystawy i koncerty. Zrodziła się wreszcie nowa dyscyplina artystyczna Dialogu: pokazy mody. Na wybiegu pojawily się kolekcje polskich i izraelskich projektantów.

Rok 2005 był rokiem szczególnym dla Witolda Knychalskiego, który został uhonorowany Srebrnym Medalem „Zasłużony Kulturze Gloria Artis”; wraz z organizatorami Festiwalu Dialogu Czterech Kultur otrzymał też dyplom Ministra Spraw Zagranicznych RP za międzynarodową promocję Polski, a także zyskał tytuł honorowego „Sternika Łodzi 2005 ” W poprzednim roku wyróżniono go też medalem „Zasłużony dla tolerancji”. Tak szerokie uznanie dla działalności twórcy Festiwalu, podkreślanie międzynarodowegowymiaru FD4K, mogłoby sugerować, że będzie się on dynamicznie i harmonijnie rozwijać. Sam Knychalski zaznaczał, że osiągnięty kształt wydarzenia "to cały czas początek drogi”"41.

A jednak V Dialog, który odbywał się w dniach 1-10 września 2006 roku ujawnił już skalę nieporozumień i kryzysów, które wokół niego narosły. Na miesiąc przez inauguracją kolejnej edycji FD4K odszedł ze stanowiska (zabierając ze

40 W ten sposób artysta sam określał swoją działalność, zob.: Gerhard Jürgen Blum-Kwiatkowski, Małgorzata Ludwisiak, Rozmowa z Gerhardem Jürgenem Blumem-Kwiatkowskim, „Gazeta Wyborcza - Łódź” (25 sierpnia 2005), https://lodz.wyborcza. pl/lodz/7,35135,2883792.html (dostęp: 10.11.2016).

41 Witold Knychalski, Katalog: Program Festiwalu Dialogu Czterech Kultur 2005, s. 2. 
sobą doświadczonych współpracowników) dyrektor artystyczny imprezy - Michał Merczyński. Zmniejszała się liczba sponsorów Festiwalu i nadal topniał jego budżet. Problematyczna stawała się współpraca z głównym partnerem - TVP, który nie zadbał nawet o stosowną reklamę.

Zaawansowanie prac nad programem 5. FD4K, oczekiwania publiczności i kontrahentów, spowodowały, że pomimo kłopotów V Dialog odbył się zgodnie z planem: w dniach 1-10 września 2006 roku. Zyskał też patronat honorowy Premiera RP oraz niesłabnące zainteresowanie środowisk opiniotwórczych. Przy Festiwalu akredytowało się kilkudziesięciu dziennikarzy, w tym także sprawozdawcy z Niemiec, Szwecji i Rosji42. I właśnie kultura rosyjska - w związku z obchodzonym w Łodzi Rokiem Rosyjskim - stała się wiodącym obszarem festiwalowych prezentacji.

Najważniejszym gościem z Rosji był słynny moskiewski Teatr na Tagance ze spektaklem Wysocki (w reżyserii Jurija Lubimowa), dwukrotnie zagranym w Teatrze Nowym. Swoistym pendant do przedstawienia było spotkanie z publicznością Daniela Olbrychskiego, który w wieczorze pt. Mój przyjaciel Wołodia wspominał Władimira Wysockiego i recytował jego wiersze we własnym tłumaczeniu. Odbyła się też wystawa: Wysocki. Czy pamiętasz jeszcze tamten dom?... przywieziona z Muzeum Wysockiego w Koszalinie.

Wyjątkowym festiwalowym przeżyciem był koncert symfoniczny dzieł światowej sławy kompozytorki rosyjskiej tatarskiego pochodzenia - Sofii Gubajduliny. W kościele św. Mateusza zagrali jej utwory muzycy z doskonałego AUKSO - Orkiestry Kameralnej Miasta Tychy, pod dyrekcją Marka Mosia. Filharmonia Łódzka przygotowała koncerty muzyki Arama Chaczaturiana i Dymitra Szostakowicza, a w Katedrze św. Aleksandra Newskiego trzykrotnie wystąpily chóry cerkiewne.

Prawdziwą sensacją programową okazał się cykl Czy prawda czasu, czy prawda ekranu?, prezentujący najwybitniejsze filmy rosyjskiego porewolucyjnego kina niemego (m.in.: Siergieja Eisensteina, Aleksandra Miedwiedkina, Wsiewołoda Pudowkina, Lwa Kuleszowa czy Dżigi Wiertowa). Wszystkie projekcje odbywały się z udziałem taperki - Aleksandry Kędry. Do przeglądu rosyjskiej kultury włączały się także lokalne instytucje, proponując wybrane wydarzenia ze swojego repertuaru lub przygotowując nowe. $\mathrm{W}$ tym nurcie Teatr Jaracza pokazał słynny monodram Niżyński (reż. Waldemar Zawodziński), ze znakomitym Kamilem Maćkowiakiem, a także premierowy wieczór romansów rosyjskich - Mów mi o miłości. Teatr Nowy zaoferował Plac św. Wtodzimierza Ludmily Razumowskiej

42 Michał Lenarciński, Kończy się V Festiwal Dialogu Czterech Kultur, „Dziennik Łódzki” (9 września 2006), https://e-teatr.pl/konczy-sie-v-festiwal-dialogu-czterech-kultur-a28442 (dostęp: 11.10.2016). 
(reż. Tomasz Zygadło). Swoje oferty dołożyły też: teatry lalkowe, AOIA, Śródmiejskie Forum Kultury, Poleski Ośrodek Sztuki (tu m.in. recital Oleny Leonenko Noc $z$ Wertyńskim).

Cechą charakterystyczną 5. FD4K było usytuowanie wielu imprez festiwalowych na terenie otwartego w roku 2006 wielkiego centrum handlowo-rozrywkowego Manufaktura. Ta nowa agora miasta jeszcze mocniej zintegrowała publiczność Dialogu, stając się miejscem spotkań i wymiany poglądów. Przestrzeń Łodzi - tak istotna we wszystkich odsłonach Festiwalu - zyskała w obszarze jurydyki Poznańskiego obiecujące kulturowe forum. To tu zaprezentowano multimedialne widowisko Zaczarowane miasto Sławomira Łosowskiego, w którym utworom zespołu Kombi towarzyszyły pokazy archiwalnych zdjęć Łodzi. Także w Manufakturze odbyły się dwa widowiska wyreżyserowane przez Piotra Trzaskalskiego: Etniczne brzmienie czterech kultur (z udziałem m.in. Kapeli ze Wsi Warszawa oraz rosyjskiego zespołu Farlanders) oraz elektryzujący publiczność koncert znakomitej izraelskiej skrzypaczki - Sophie Solomon. Artystka zagrała m.in. muzykę klezmerską, węgierską, a także swoją interpretację polskiego szlagieru Jerzego Petersburskiego - To ostatnia niedziela. Oferta muzyczna była w czasie 5. F4K wyjątkowo rozbudowana. Parada Festiwalowa z udziałem orkiestr dętych, która - oczywiście! - dotarła do Manufaktury, zakończona została koncertem rosyjskiego zespołu Back Up, ustanawiając obyczaj codziennego, wieczornego muzykowania na Rynku. W tych Koncertach w Manufakturze wzięło udział wiele wokalistek, wokalistów i zespołów, m.in.: Krystyna Prońko, Renata Przemyk, Dorota Miśkiewicz, Dikanda, GOYA, Raz Dwa Trzy, Rezerwat, Cool Kids of Death, Power of Trinity.

Muzycznych wydarzeń było jednak znacznie więcej. Udało się doprowadzić do prawykonania specjalnie przygotowanego dla Festiwalu widowiska muzycznego Bal w operze z muzyką Zygmunta Krauzego, według dzieła Juliana Tuwima (reż. Tomasz Konina). Tradycyjnie już, u św. Mateusza grali jazzmani; tym razem ze swoimi grupami wystąpili Tomasz Bielski oraz Krzysztof Ścierański, który zagrał kompozycję 4 Łódź (For Łódź), składającą się na późniejszą świetną płytę pod tym samym tytułem. W Śródmiejskim Domu Kultury pokazano widowisko muzyczne: Czy mnie jeszcze pamiętasz? (z piosenkami Czesława Niemena). W czasie V Dialogu działała też Scena Miejska w Pasażu Schillera; miłośników różnych gatunków muzyki zapraszały: Muzeum Miasta Łodzi (koncertował Bartosz Bryła), Łódzki Dom Kultury (wystąpili: Sława Przybylska; José Torres), Klub JazzGa (koncert z cyklu On Air), Club Funaberia (m.in. Normalsi, Superpuder).

Słynący z multimedialności i łączenia czterech kultur Festiwal tym razem także nie zrezygnował $\mathrm{z}$ ich prezentacji. I tak: $\mathrm{z}$ Jerozolimy przyjechał jeden $\mathrm{z}$ najważniejszych izraelskich teatrów - The Khan Theatre, z przedstawieniem The Town of the Little People (reż. Ofira Henig). Spektakl stanowił sceniczną refleksję 
nad Holokaustem, opartą na opowiadaniach Szolema Alejchema. Teatr Biuro Podróży pokazał na Rynku Starego Miasta plenerowe widowisko - Kim jest ten człowiek we krwi (wg Makbeta Williama Shakespeare’a, reż. Paweł Szkotak). Nad Piotrkowską zawisły Rzeźby balansujące Jerzego Kędziory. Odbyło się wiele różnych spektakli (dramatycznych, muzycznych, tanecznych), performansów, happeningów, wernisaży wystaw (malarstwa, fotografii), spotkań literackich, paneli dyskusyjnych i projektów edukacyjnych (m.in. Wieża Babel). Pomimo kryzysu organizacyjnego związanego z odejściem Merczyńskiego, ciągnącymi się za Festiwalem długami i topniejącą dotacją, 5. FD4K miał w swoim repertuarze 90 pozycji ${ }^{43}$. Było to jednak także znakiem nasilającej się skłonności organizatorów do wpisywania $\mathrm{w}$ program nieomal wszystkich wydarzeń, które odbywały się w mieście i w jakimś stopniu (często niewielkim) korespondowały z ideą Dialogu. Poszerzało się też terytorium Festiwalu, który pojawił się w Piotrkowie Trybunalskim przy okazji koncertu zespołu Myslovitz.

Rok 2006 przyniósł tragiczne wydarzenie w dziejach Festiwalu Dialogu Czterech Kultur. 12 września 2006 roku, dwa dni po zakończeniu piątej edycji Festiwalu, zmarł Witold Knychalski - jego wizjoner i twórca.

Stowarzyszenie „Łódź - Ziemia Przyszłości” zostało rozwiązane w lutym 2007 roku $^{44}$, ale VI Dialog, zorganizowany przez Fundację Festiwalu, odbył się zgodnie z planem: od 31 sierpnia do 9 września 2007 roku. Dyrektorem 6. FD4K nadal był Okuński, dyrektorem artystycznym został natomiast znany reżyser Piotr Trzaskalski (współpracujący z Dialogiem w poprzednim roku). Powołano także dyrektora programowego - Michała Lenarcińskiego, łódzkiego dziennikarza i publicystę, oraz Radę Programową.

VI Festiwal zaproponował znów bardzo rozbudowany program, przede wszystkim - muzyczny. Wyjątkowym wydarzeniem w historii imprezy był recital światowej sławy sopranistki amerykańskiej - Barbary Hendricks. W Filharmonii Łódzkiej artystka zaśpiewała m.in. utwory Roberta Schumanna i Gustava Mahlera, ale także pieśni kabaretowe Arnolda Schönberga i utwory Kurta Weilla. Entuzjastyczna owacja publiczności skłoniła śpiewaczkę do trzykrotnego bisowania. Znacząca była także reprezentacja wybitnych pianistów: Ning An, Edward Auer, Markus Groh.

43 Zob.: XV edycja Przyszłość bez powrotu V edycja (od 01.09.2006 do 10.09.2006), strona Centrum Dialogu im. Marka Edelmana, https://e-teatr.pl/iv-edycja-e328 (dostęp: 10.05.2017).

44 Michał Lenarciński, O festiwal możemy być spokojni, „Dziennik Łódzki” (8 stycznia 2007), https://e-teatr.pl/Lodz-bedzie-festiwal-dialogu-czterech-kultur-a34113 (dostęp: 9.10.2016). 
6. FD4K gościł też Tommy’ego Emmanuela (Australia), uznawanego za jednego z najlepszych współczesnych gitarzystów akustycznych, prekursora i mistrza techniki fingerstyle, który nieoficjalnie, dwoma koncertami, zainaugurował w Filharmonii VI Dialog. Także polscy muzycy wyróżniali się poziomem i wirtuozerią swojego wykonawstwa. Zagrali kameraliści z Kwartetu Śląskiego, można też było wysłuchać laureatki XIII Międzynarodowego Konkursu Skrzypcowego im. Henryka Wieniawskiego - Agaty Szymczewskiej.

Efektowne były występy artystów reprezentujących inne gatunki muzyki. W kościele św. Mateusza koncert poświęcony pamięci Witolda Knychalskiego - miłośnika jazzu - dała świetna polska wokalistka Aga Zaryan. Publiczność entuzjastycznie przyjęła także występ norweskiego trębacza, jednego z twórców nu jazzu, Nilsa Pettera Molværa. Zagrali też m.in.: Leszek Możdżer, Mazzoll Tow oraz free jazzowy kwartet Mikołaja Trzaski. W klubie JazzGa odbywały się wieczory z cykli: Jazzga Off, On Air. Podobnie jak w ubiegłorocznej edycji, koncerty rockowe i popowe prezentowano na (znacznie powiększonej) scenie plenerowej w Manufakturze, gdzie przed kilkutysięczną widownią wystąpił m.in. zespół Alphaville czy też orkiestra Fanfara Ciocarlia, wykonująca tradycyjną muzykę bałkańską.

W Manufakturze można było także uczestniczyć w widowiskach teatralnych. Wystąpił tu m.in. Polski Teatr Tańca - Balet Poznański ze swoim ekstatycznym spektaklemWalk@ karnawału z postem w reżyserii i choreografii Ewy Wycichowskiej, a Teatr Wielki pokazał plenerową inscenizację opery komicznej Stanisława Moniuszki Hrabina. W nurcie teatralnym Festiwalu zaprezentowano wiele innych spektakli, w tym przedstawienie The Father (wg Ojca Augusta Strindberga, w reż. Yossi Polaka) jednego z najważniejszych izraelskich teatrów - The Cameri Theatre of Tel Aviv. Nie zabrakło zespołów polskich: Stowarzyszenie Teatralne CHOREA przedstawiło Śpiewy Eurypidesa; Teatr im. J. Szaniawskiego z Wałbrzycha - Iwonę, księżniczkę Burgunda Witolda Gombrowicza, a łódzkie sceny przygotowały na Festiwal premierowe widowiska: m.in. Zabawy..., wg Zabaw na podwórku izraelskiej pisarki Edny Mazyi, w reżyserii Tomasza Gawrona (Teatr Nowy, 2 września 2007) i prapremierę Brzydala Mariusa von Mayenburga, w reżyserii Grzegorza Wiśniewskiego (Teatr Jaracza, 8 września 2007).

Spośród wydarzeń filmowych na wyróżnienie zasługuje przegląd twórczości Zbigniewa Rybczyńskiego. Odbyły się także projekty ujęte w cykle zatytułowane: Żydowskie losy, żydowska tożsamość i Kino wspótczesne. Natomiast w dziedzinie sztuk plastycznych, wśród wielu wernisaży wyróżniały się: wystawa Sztuka buntu, czyli malarstwo drugiej awangardy rosyjskiej (underground z lat 19501980), ze zbiorów Kendy i Jacoba Bar-Gera oraz wystawa fotografii Evy Rubinstein. We wszystkich nurtach VI Dialogu przeprowadzono spotkania dyskusyjne, konferencje, organizowano kabarety, wycieczki, parady uliczne - liczba wydarzeń 
osiągnęła ekstremalny poziom ponad $150^{45}$. A całość zakończyła gwiazda izraelskich estrad David D’Or, któremu towarzyszył „balet ognia”...

Szósta edycja Festiwalu przyniosła także rozważania w prasie, podsumowujące charakter i sposób organizacji wydarzenia. Nie były to jednak refleksje krzepiące. Dziennikarze podkreślali to, co było codziennym doświadczeniem publiczności: nadmiar imprez, których pojawienia się w programie Dialogu często nie dawało się uzasadnić. Wspaniała idea FD4K zaczynała się zatracać w gąszczu eventów. Rozrastała się przestrzeń Festiwalu, ogarniając miasta w województwie. Imprezy pod szyldem FD4K odbywały się m.in. w Koluszkach, Rawie Mazowieckiej, Uniejowie, Pabianicach czy Łowiczu. Recenzenci zwracali uwagę na absurdalne rozdęcie repertuaru Festiwalu i jego chaotyczny układ, na włączanie do niego mnóstwa aktualnych miejskich wydarzeń, niezależnie od ich rzeczywistego przystawania do idei Dialogu; na nieuzasadnione poszerzanie zespołu kierowniczego, niewłaściwą dystrybucję biletów, błędy w organizacji wydarzenia i w jego medialnej oprawie, a przede wszystkim - na niepokojące przekształcanie FD4K w imprezę o charakterze ludycznej zabawy. Jak przestrzegali Krzysztof Kowalewicz i Jakub Wiewiórski: „To początek przeradzania się festiwalu $\mathrm{z}$ aspiracjami w zwyczajny festyn" 46 . Problemem był poziom artystyczny wielu wydarzeń, często włączanych do programu z racji serwitutów wobec lokalnych instytucji i władz.

Zmieniała się też struktura organizacyjna FD4K. Pod koniec roku 2007, dzięki działaniom żony Witolda Knychalskiego - Barbary, powołano do istnienia nową instytucję: Miasto Dialogu, która miała być odpowiedzialna za organizację nowych edycji. Powstanie tej jednostki było wynikiem umowy między Urzędem Miasta Łodzi a Fundacją Festiwalu Dialogu Czterech Kultur - posiadającej prawa autorskie do wydarzenia. Formalnie Miasto Dialogu zaczęło działać dopiero 1 lutego 2008 roku. Niestety, już wcześniej pojawiły się - i z biegiem czasu narastały - konflikty między Fundacją a dyrektorem Okuńskim, związanym z Towarzystwem na Rzecz Dialogu Kultur „Łódź - Ziemia Przyszłości”, które organizowało Festiwal w czasie jego pierwszych edycji, do czasu popadnięcia w tak wielkie zadłużenie, że nie mogło dłużej wykonywać swojej statutowej działalności. Organizację wydarzenia przejęła wówczas Fundacja Festiwalu.

45 Zob.: strona Centrum Dialogu im. Marka Edelmana, XV edycja Przyszłość bez powrotu VI edycja (od 31.08.2007 do 09.09.2007), https://e-teatr.pl/vi-edycja-e838 (dostęp: 15.05.2017).

46 Krzysztof Kowalewicz, Jakub Wiewiórski, Festiwal błędów i bylejakości, „Gazeta Wyborcza - Łódź” (8 września 2007), archiwizowane na stronie Encyklopedii teatru polskiego, http://encyklopediateatru.pl/artykuly/43807/festiwal-bledow-i-bylejakosci (dostęp: 20.11.2016). 
Okuński uważał za niepotrzebne tworzenie kolejnej instytucji, mającej sterować Dialogiem. Nieporozumienia miały szerszy zakres i w kolejnych miesiącach się pogłębiały ${ }^{47}$. Ciągnące się od pierwszej edycji zobowiązania finansowe - choć sukcesywnie spłacane - nadal wymagały też pokrycia.

Mimo spektakularnych występów wybitnych artystów i sukcesów frekwencyjnych stało się jasne, że sytuacja Festiwalu wymaga uporządkowania warstwy artystycznej i przepracowania modelu organizacyjnego. 1 lutego 2008 roku rozpoczęło działalność Miasto Dialogu, które przygotowało siódmą (i ósmą) edycję Festiwalu. Prezesem instytucji została Barbara Knychalska; dyrektorem Miasta Dialogu oraz Festiwalu - Katarzyna Knychalska (córka założyciela FD4K). Natomiast na stanowiska dyrektorów artystycznych powołano Grzegorza Niziołka i Agatę Siwiak - wybitne osobowości polskiej kultury ${ }^{48}$. Proponowane przez nich wydarzenia zostały (prowokacyjnie) sprofilowane tematycznie zgodnie z brzmieniem fraz znanego wierszyka Władysława Bełzy: Kto ty jesteś? - Ojcowie (2008 r.); Gdzie ty mieszkasz? - Terytorium (2009 r.) i skupione wokół zagadnień dotyczących pamięci, tożsamości i sposobów ich dzisiejszego przepracowania. Pozwalało to także przypomnieć odbiorcom Dialogu rodowód Łodzi i przemiany, jakim podlegała.

VII Dialog odbywał się w dniach 5-12 września 2008 i obejmował 50 różnych wydarzeń, ujętych i rozwijanych w ramach spójnych bloków i cykli49. Część $\mathrm{z}$ tych propozycji stanowiły własne produkcje festiwalowe, choć nie było to jeszcze normalną praktyką. Wszystkie prezentowane były w różnych przestrzeniach Łodzi, także w tych dotąd niewykorzystywanych, jak np.: podwórko przy ulicy Wschodniej, dawna elektrownia Scheiblera, kamienica przy Piotrkowskiej czy

47 Jędrzej Słodkowski, Jakub Wiewiórski, Festiwal Dialogu Czterech Kultur. Polityka bez kultury, „Gazeta Wyborcza - Łódź” (18 maja 2010), http://lodz.wyborcza. pl/lodz/1,35136,7896488,Festiwal_Dialogu_Czterech_Kultur_Polityka_bez_kultury.html (dostęp: 10.09.2016); Michał Lenarciński, Towarzystwo na rzecz Dialogu Kultur do likwidacji, „Dziennik Łódzki” (10 lutego 2007), archiwizowane na stronie Encyklopedii teatru polskiego, http://www.encyklopediateatru.pl/artykuly/35037/ lodz-towarzystwo-na-rzecz-dialogu-kultur-do-likwidacji (dostęp: 10.09.2016); Krzysztof Kowalewicz, Wielkie zmiany 4 kultur, „Gazeta Wyborcza - Łódź” (7 stycznia 2008), archiwizowane na stronie Encyklopedii teatru polskiego, http://encyklopediateatru.pl/ artykuly/49521/lodz-zmiany-w-dialogu-czterech-kultur (dostęp: 20.10.16); Łukasz Biskupski, Tomasz Majewski, Festiwal Dialogu...

48 Zob.: [informacja własna], Łódź. Powstało Miasto Dialogu, http://encyklopediateatru.pl/artykuly/51283/lodz-powstalo-miasto-dialogu (dostęp: 13.09.2016).

49 Zob.: strona Centrum Dialogu im. Marka Edelmana, XV edycja Przyszłość bez powrotu VII edycja (od 05.09.2008 do 12.09.2008), https://e-teatr.pl/ przyszlosc-bez-powrotu-e3845 (dostęp: 10.10.2016). 
neorenesansowy pałac dawnego Towarzystwa Kredytowego Miejskiego, który był wówczas nieomal ruiną 50 .

Hasłem przewodnim VII Festiwalu byli „Ojcowie”, co miało problematyzować zagadnienie kształtowania tożsamości, sens (nie)obecności ojców w życiu kolejnych pokoleń, powracanie i wypieranie pamięci o przeszłości. Jak pisali organizatorzy: artyści, podejmując motyw ojca, „[... ] przyglądają się mu na przecięciu tego, co osobiste i zbiorowe, prywatne i publiczne. [...] Pytają o to, jak idea ojca kształtuje naszą tożsamość narodową, kulturową i religijną, a co za tym idzie, jak wpływa na nasze poczucie przynależności, osierocenia bądź wykluczenia”. Tak sformułowane zagadnienie miało nawiązywać i do dziejów Łodzi, i do jej teraźniejszości. Łódź postrzegana była w kategoriach „miasta osieroconego, znajdującego się w momencie kulturowej transformacji”"51. Inaugurujący oficjalnie VII Dialog wykład honorowego gościa - austriackiego pisarza, publicysty i tłumacza Martina Pollacka, zatytułowany Nieznany - mój ojciec, otworzył wiodący temat Festiwalu.

Motyw „ojców” najsilniej został podjęty i przepracowany w propozycjach teatralnych 7. FD4K. Kilka z nich miało wyjątkową rangę i znaczenie. Jednym z najciekawszych wydarzeń VII Dialogu był z pewnością słynny spektakl Die Hamletmaschine [HamletMaszyna] Heinera Müllera (Deutsches Theater Berlin) $\mathrm{w}$ inscenizacji pochodzącego z Bułgarii niemieckiego reżysera i aktora - Dimitra Gotscheffa, który grał także postać Hamleta. Polską premierę wzbogacily projekcja filmu Die Zeit ist aus den Fugen [Ten czas jest kością wylamaną w stawie, reż. Christopher Rüter] rejestrującego powstawanie przedstawienia przygotowanego przez samego Müllera w Deutsches Theater w Berlinie Wschodnim, w rewolucyjnym okresie: 29 sierpnia 1989 - 24 marca 1990 roku, a także sesja naukowa poświęcona twórczości wybitnego dramaturga. Temat „Ojcowie” podjął również teatr Schauspielhaus Zürich, w zbliżonym do konwencji verbatimu spektaklu Väter [Ojcowie], zainscenizowanym przez „kultowego” łotewskiego reżysera - Alvisa Hermanisa. Przedstawienie stanowiło efekt pracy artysty z trójką wykonawców: Łotyszem i Niemcem (aktorzy) oraz łotewskim Rosjaninem (malarz i fotografik, teatralny naturszczyk), którzy opowiadają na scenie autentyczne historie o swoich ojcach. Choć w rzeczywistości - jak pisała Anna R. Burzyńska - „[... ] to nie

50 Pałac, zbudowany według projektu słynnego łódzkiego architekta Hilarego Majewskiego na przełomie lat 70. i 80. XIX wieku został wspaniale odremontowany trzy lata później - w roku 2011. Warto przypomnieć, że na jego frontonie widnieje napis znaczący dla losów Łodzi - Virbus Unitis [wspólnymi siłami].

51 Cyt. za: Festiwal Dialogu Czterech Kultur, http://www.4kultury.pl, archiwizowane na stronie www.e-teatr.pl, za: https://culture.pl/pl/wydarzenie/festiwal-dialoguczterech-kultur-2008 (dostęp: 16.08.2010). 
synowie-aktorzy opowiadają o swoich ojcach, ale to ojcowie mówią poprzez nich”52. A Łukasz Drewniak konstatował: „Narratorzy Hermanisa ośmieszają swych ojców i uwznioślają w tej samej chwili. [... ] powstaje przedziwna mieszanka faktu i iluzji. Lekka, żartobliwa tonacja spektaklu skrywa melancholię przemijania, piekło sztafety pokoleń" 53 . Trzeci spektakl, zrealizowany w teatralnym nurcie interpretacji wiodącego tematu 7. FD4K, był produkcją własną Festiwalu i został zamówiony u Michała Borczucha. Przedstawienie pt.: Wieczór sierot, choć oparte na książkach Janusza Korczaka o królu Maciusiu, stanowiło jednak „[...] gorzko-ironiczną alternatywę dla upraszczającej martyrologicznej lektury pism Korczaka"54. Spektakl zrealizowano we wnętrzach zrujnowanego pałacu Towarzystwa Kredytowego, gdzie: „Wśród łuszczących się ścian, pod blednącymi plafonami [Borczuch - S.Sz.] zwołał konferencję dzieci [...] planujących rewolucję przeciw dorosłym”55. Zarówno Hermanis, jak i Borczuch: „[...] pokazali świat, w którym powrót taty (tego męskiego, twardego, wiecznie nieobecnego wzorca, jaki znamy z opowieści i fotografii rodzinnych) jest już niemożliwy, a którego brak leży u podstaw erozji kultury" 56 . Swoistym dopełnieniem premiery była debata przygotowana przez „Krytykę Polityczną” - Korczak: polityka dzieciństwa oraz spacer uczestników Festiwalu szlakiem sierocińców Litzmannstadt Ghetto. Zaproszona na 7. FD4K izraelska grupa młodych performerów - Public Movement - także podejmowała tematykę tożsamości, wpisując ją jednak w swoim widowisku Also Thus! „[... ] w koncepcję Łodzi jako fascynującego w rozkwicie i upadku miasta-teatru, organizując $\mathrm{w}$ różnych jego miejscach niespodziewane i kontrowersyjne akcje z pogranicza teatru i happeningu" 57.

Drugim teatralnym cyklem odwołującym się do wiodącego tematu VII Dialogu była retrospektywa twórczości Tadeusza Kantora. Nagrania przedstawień zostały skonfrontowane $\mathrm{z}$ prezentacjami obiektów-rekwizytów z najważniejszych spektakli artysty, a także z projekcjami filmów dokumentalnych, rejestrujących m.in. jego wypowiedzi. Blokowi wydarzeń towarzyszyły wykłady badaczy,

52 Anna R. Burzyńska, Dziwna forma nieśmiertelności, „Tygodnik Powszechny” 2008, nr 38, https://e-teatr.pl/dziwna-forma-niesmiertelnosci-a58443 (dostęp: 13.09.2016).

53 Łukasz Drewniak, „Ojcowie” Hermanisa: apoteoza przez ośmieszenie, Dziennik online: https://e-teatr.pl/ojcowie-hermanisa-apoteoza-przez-osmieszenie-a58212 (dostęp: 10.09 .2016$)$.

54 Anna R. Burzyńska, Dziwna forma...

55 Joanna Derkaczew, Widmo ojca krąży nad Łodzia, „Gazeta Wyborcza” (11 września 2008), https://e-teatr.pl/widmo-ojca-krazy-nad-Lodzia-a58198 (dostęp: 8.08.2021).

56 Ibidem.

57 Anna R. Burzyńska, Dziwna forma... 
podejmujących refleksję nad dziełami Kantora (np. wykład Małgorzaty Dziewulskiej Synowie, Ojcowie, Umarli w teatrze Tadeusza Kantora).

W repertuarze szóstej edycji nie zabrakło także sztuki filmowej. Organizatorzy zaproponowali przeglądy filmów: Aleksieja Germana (autora m.in. obrazu Mój przyjaciel Iwan Łapszyn, uznawanego za jeden z najlepszych filmów radzieckich) oraz wybitnej radzieckiej i ukraińskiej reżyserki - Kiry Muratowej. Artystka ta przyjechała do Łodzi.

Niezwykle atrakcyjna była oferta muzyczna 7. FD4K, przede wszystkim za sprawą występującej w Łodzi, w dniach 6-10 września, rewelacyjnej chicagowskiej Rob Mazurek - Exploding Star Orchestra. Jak pisała Monika Wasilewska:

Big-band kornecisty Roba Mazurka, jedna z najwspanialszych dużych grup okołojazzowych na świecie, zagrał w Wytwórni, świadcząc o odnowie Festiwalu Dialogu Czterech Kultur. Grupie wybornych muzyków młodego i średniego pokolenia z Chicago, wzbogaconych o instrumentalistów znanych z wrocławskiego Robotobiboka, towarzyszyła legenda saksofonu z Wietrznego Miasta - dziarski 79-latek Fred Anderson ${ }^{58}$.

Jędrzej Słodkowski uzupełniał relację z muzycznej oferty Festiwalu następująco: „Wspaniale wypadły też koncerty Kwartludium z Sebastianem Meissnerem w Scheiblerowskiej elektrowni i Hadag Nahash w podwórku przy Wschodniej 50"59. Aby nie zatracić całkiem nastroju karnawału, w Manufakturze grały także zespoły uprawiające muzykę etniczną czy rockową i hip-hopową, np. Kapela Ze Wsi Warszawa i mołdawska grupa Zdob şi Zdub.

Podobnie jak w obszarze teatru, również $\mathrm{w}$ dziedzinie sztuk wizualnych pojawiły się projekty przygotowane specjalnie dla Festiwalu. Dzięki zaproszeniu do współpracy piętnaściorga twórców, powstała zbiorowa wystawa C.D.N., prezentująca premierowe prace, m.in.: Piotra Bosackiego, Konrada Kuzyszyna, Józefa Robakowskiego, Ryszarda Waśki czy Grupy Sędzia Główny. Drugą festiwalową ekspozycją sztuki współczesnej, w której polscy artyści i artystki zmagali się z tematem ojcostwa i jego wzorcami kulturowymi, był wernisaż Master \& Monster. Wystawy zorganizowano w opuszczonej, dawnej willi Ludwika Geyera - ojca łódzkiego przemysłu; we wrześniu 1939 roku został tu

58 Monika Wasilewska, wypowiedź w: Jakub Wiewiórski, Łódzkie sukcesy w kulturze 2008, „Gazeta Wyborcza - Łódź” (31 grudnia 2008), https://e-teatr.pl/ Lodzkie-sukcesy-w-kulturze-2008-a63403 (dostęp: 8.08.2021).

59 Jędrzej Słodkowski, Dialog kultur się ożywia, „Gazeta Wyborcza - Łódź” (15 września 2008), https://e-teatr.pl/dialog-kultur-sie-ozywia-a58329 (dostęp: 13.09.2016). 
zastrzelony przez Gestapo jego wnuk, łódzki przemysłowiec i społecznik - Robert Geyer. Specjalnym gościem 7. FD4K była rezydująca w Łodzi przez kilka tygodni Joanna Rajkowska, co zaowocowało stworzeniem projektu dotyczącego Rewolucji roku 1905. Artystka wykorzystała do jego powstania znajdujące się w zbiorach Muzeum Tradycji Niepodległościowych w Łodzi archiwalne fotografie $\mathrm{z}$ lat 1905-1908.

Zaplanowanie i przeprowadzenie VII Festiwalu zdecydowanie odbiegało od sześciu wcześniejszych jego edycji, zarówno pod względem programowym, jak i organizacyjnym. Festiwal zyskał konkretną myśl przewodnią, stawał się rzeczywistym dialogiem - za pośrednictwem sztuki - na temat trudnych, wypieranych ze świadomości tematów, także tych dotyczących Łodzi. Nie zaniedbując promocji rodzimych artystów, Dialog przesunął jednak uwagę ku starannie wyselekcjonowanym wydarzeniom o skali ogólnoeuropejskiej i z tej perspektywy proponował refleksję nad tym, co lokalne. Europejska była też oprawa i styl nowego Festiwalu. Jak pisała Anna R. Burzyńska:

Tegoroczna edycja to ogromny, kompleksowy projekt, przemyślany bardzo starannie - od arcybogatego programu artystycznego i edukacyjnego, poprzez potężny katalog, w którym przewodnie kwestie Festiwalu analizują m.in. Maria Janion, Herta Müller, Krzysztof Pomian i Adam Lipszyc, aż po spójną koncepcję plastyczną plakatów, koszulek, gadżetów festiwalowych oraz pomysłowe wykorzystanie niesamowitej łódzkiej architektury ${ }^{60}$.

Dzięki nowej formule wydarzenia i doświadczeniu animatorskiemu jego dyrektorów artystycznych udało się porzucić „nostalgiczno-folkowy” [określenie Joanny Derkaczew] charakter poprzednich edycji, uniknąć drażniących „dziesiątek imprez dla wszystkich i dla nikogo" i „pustych miejsc dla VIP-ów”61. Choć trzeba też zaznaczyć, że entuzjazm wobec rewolucyjnej nowej odsłony FD4K nie był powszechny. Na łamach lokalnej prasy sukcesywnie pojawiała się krytyka - jak twierdzono - zanadto elitarnego, hermetycznego i „niszowego” charakteru wydarzenia, zarzucano Festiwalowi, iż: „Bal dla ludzi zmienił się w akademię dla wybrańców"62.

Jednak animatorzy Dialogu, niezrażeni podobnymi opiniami, zaplanowali ósmą edycję Festiwalu jako kontynuację prowadzonej za pomocą sztuki, pogłębionej, krytycznej refleksji nad zagadnieniem kształtowania się i odzyskiwania

60 Anna R. Burzyńska, Dziwna forma...

61 Jędrzej Słodkowski, Dialog kultur ...

62 Dariusz Pawłowski, Niska sztuka wysoka, Polska „Dziennik Łódzki” (16 września 2008), https://e-teatr.pl/niska-sztuka-wysoka-a58342 (dostęp: 16.10.2016). 
tożsamości. Podobnie jak w poprzednim roku, 8. FD4K został potraktowany jako projekt badawczy. Tym razem jego hasłem przewodnim był kolejny wątek wyjęty z wierszyka Bełzy: Gdzie ty mieszkasz? - Terytorium. Wiele festiwalowych wydarzeń nawiązywało do historii i przestrzeni Łodzi. Agata Siwiak podkreślała: „[... ] rozwój Łodzi dokonał się w niecałe 200 lat. Wydało się nam naturalne, żeby to pokazać. [... ] Festiwalowe działania nazwaliśmy akupunkturą miejską: nakłuwaniem osamotnionych, pustych miejsc. Kapitałem Łodzi są jej przestrzenie $[\ldots]^{63}$.

Wydobywanie i odzyskiwanie łódzkich przestrzeni: terytorialnych, mentalnych, wyobraźniowych było ważnym zadaniem VIII edycji Festiwalu. W historii Łodzi wyróżnione zostały trzy strefy przestrzenne: „wojenna” - dotycząca historii i pamięci, „wolna” - odwołująca się do kontekstów rewolucji i wyzwolenia oraz „ziemia obiecana” - odnosząca się do nadziei i przyszłości ${ }^{64}$. $\mathrm{W}$ tym kontekście jednym $\mathrm{z}$ najważniejszych wydarzeń (nie tylko tej edycji Festiwalu) stał się, inaugurujący 8. FD4K, całonocny wernisaż wystawy przygotowanej przez Adama Budaka (kuratora sztuki współczesnej w Kunsthaus Graz am Landesmuseum Joanneum w Grazu) pt.: Anabasis. Rytualy powrotu do domu. Multimedialna wystawa prezentowana w willi Ludwika Grohmana (jednym $\mathrm{z}$ „osamotnionych”, niedostępnych łódzkich miejsc) gromadziła instalacje (przestrzenne i dźwiękowe), obiekty, rzeźby, malarstwo, fotografię i sztukę wideo. Ekspozycja stanowiła kolejną własną produkcję festiwalową - została przygotowana specjalnie na Dialog przez dwadzieścioro siedmioro wybitnych artystek i artystów z całego świata. Obejmowała dzieła m.in.: Heleny Almeidy, Mieke Bal, Yael Bartany, Elizabeth Diller, Marine Hugonnier, Sharon Lockhart, Ernesto Neto, berlińskiego duetu Elmgreen \& Dragset. Dzieła te odnosiły się do emocji, jakie wywołuje w nas myśl o domu - terytorium najbliższym. Osobną część wystawy stanowiła prezentacja Instant Light Andrieja Tarkowskiego, czyli unikatowy zbiór 80 polaroidów słynnego twórcy sztuki filmowej, który pokazano w willi brata Ludwika - Henryka (gdzie mieści się wyjątkowe w Łodzi miejsce - Muzeum Książki Artystycznej, założone przez Janusza i Jadwigę Tryznów). Wystawie towarzyszyły także spotkania z twórcami, performanse i projekcja Zwierciadła Tarkowskiego. Projekt ten wyjątkowo mocno wpisywał się w najważniejszą ideę Festiwalu. Organizatorzy pisali:

63 Cyt. za: Monika Wasilewska, Katarzyna Rakowska, $W$ strefie wojennej i w wolnej strefie, „Gazeta Wyborcza - Łódź” (24 sierpnia 2009), https://e-teatr.pl/Lodz-lupa-i-klatana-festiwalu-dialogu-czterech-kultur-a76539 (dostęp: 10.08.2016).

64 Zob.: Marta Olejniczak, Festiwal Dialogu Czterech Kultur. Odstona Pierwsza, portal: Nowa Siła Krytyczna (8 września 2009), https://e-teatr.pl/festiwal-dialoguczterech-kultur-odslona-pierwsza-a77003 (dostęp: 10.10.2016). 
Tytuł wystawy [...] przywołuje jako metaforę wędrówki mitycznych bohaterów. Cel, do którego zmierzali i sam akt powrotu znajdują się w centrum zainteresowania zaproszonych do projektu artystów. [... ] wystawa podejmuje problem ontologii i przeznaczenia miejsca, w którego kontekście artyści mierzą się z uniwersalnym pytaniem o zakorzenienie, powrót i kształtowanie tożsamości. Naświetleniu ulegają napięcia między przestrzenią prywatną a publiczną, tym, co wewnętrzne i zewnętrzne, architekturą i miastem, przynależnością (belonging) a tęsknotą (longing). Łódź, gdzie społeczeństwo uległo nagłej transformacji, to w kontekście polskim miasto nieustannego przychodzenia i odchodzenia. Jego okaleczona historia daje świadectwo przesunięć, jakie zachodzą zarówno w przestrzeniach miejsca, jak i sposobach jego doświadczania. Wieloznaczność i nieoczywistość pojęć, takich jak dom czy powrót, otwiera pole do przyjrzenia się mechanizmom pamięci, rekonstrukcji, zadomowienia, wreszcie próbie identyfikacji miejsca 65 .

Natomiast zdaniem krytyków wystawę Anabasis:

[...] można określić jako „terapię przestrzeni miejskiej” i dokonywaną środkami sztuki rewitalizację tkanki społecznej. [...] Kontynuacji strategii terapii przestrzeni miejskiej można się dopatrzyć w sytuowaniu najważniejszych wydarzeń festiwalu w przestrzeniach zdegradowanych. Była to propozycja zamiany uczucia wstydu towarzyszącego mieszkańcom na formę akceptacji i spojrzenia odkrywającego niezauważane dotąd możliwości miejsc. W wielu działaniach artystycznych czytelna była intencja uczynienia $\mathrm{z}$ „niechcianych miejsc” loci communes, przywracanych miastu wraz z pamięcią, której były one nośnikiem ${ }^{66}$.

Tak pomyślany koncept miejsca i sproblematyzowanie zagadnienia (zdegradowanej) przestrzeni miejskiej - w kontekście Łodzi - znalazł swoje odzwierciedlenie także w innych wydarzeniach kreowanych przez 8. FD4K. Jednym z nich był projekt-spektakl pt. PK Kai Kołodziejczyk - tancerki, performerki i choreografki - zrealizowany na terenach nieczynnej wówczas, a jeszcze niezrewitalizowanej, elektrociepłowni EC1. Dwuczęściowe widowisko stanowiło połączenie tańca, performansu i parkouru. W jego części pierwszej publiczność podążała za traserami (zaproszonymi do projektu aktywistami Stowarzyszenia Parkour Łódź)

65 Za: Marcin Grabowiecki, Wystawa „Anabasis. Rytuaty powrotu do domu” w Eodzi, https: / /www.fotopolis.pl/newsy-sprzetowe/wydarzenia/8546-wystawa-anabasisrytualy-powrotu-do-domu-w-odzi (dostęp: 15.08.2016).Zob. też: Wydarzenia. „Anabasis. Rytuaty powrotu do domu”, wortal: http://designteka.pl/anabasis-rytualy-powrotu-dodomu.html (dostęp: 15.08.2016).

66 Łukasz Biskupski, Tomasz Majewski, Festiwal Dialogu ..., s. 49-50. 
po terenie opuszczonej elektrociepłowni, natomiast w części drugiej - oglądała występ duetu choreograficzno-muzycznego: Kaya Kołodziejczyk i kompozytor Daniel Radtke.

Jako koprodukcja berlińskiego teatru Hebbel am Ufer, wrocławskiego Teatru Polskiego oraz 8. FD4K powstał spektakl Ziemia obiecana wg Władysława St. Reymonta, w reżyserii Jana Klaty, które to przedstawienie - jak można by sądzić - wspóltworzyło strefę „ziemi obiecanej”. Jeśli dałoby się jednak utrzymać tę kategorię wobec przedstawienia Klaty, to tylko traktując ją bardzo umownie. Sam reżyser deklarował, iż „[... ] Łódź, wiele kultur, XIX wiek, narodziny słowiańskiego Nowego Jorku - jest poza orbitą naszych zainteresowań”; natomiast to, co go interesuje, to - widoczna także u Reymontowskich bohaterów - „mentalność gracza: kogoś, kto za każdym razem gra o maksymalną stawkę" oraz „natura samej gry”67. Przedstawienie, mimo że oblegane przez publiczność („200-osobowy tłum walczący między halami Unionteksu o trzy ostatnie wejściówki na $\gg$ Ziemię obiecaną «"68), ani jej, ani krytyki nie zachwyciło: „[... ] nie udało się reżyserowi przeniknąć psychiki giełdowego gracza i obnażyć mechanizmów współczesnego kapitalizmu. Zrobił to już Reymont. Klata wniósł niewiele więcej” ${ }^{69}$; „W jego przedstawieniu nie ma ani Łodzi, ani historii, ani nawet wiwisekcji kapitalizmu" 70 .

Niezwykłym festiwalowym pomysłem był natomiast performans muzyczny, „projekt operowy” rozpisany na siedem dni pt.: Barkarola. Opera przejścia na alt, interpasywne fortepiany $i$ miasto, które brzmi austriackiego kompozytora i twórcy instalacji Georga Nussbaumera. Artysta ustawił w różnych miejscach Łodzi („w miejscach ekspozycji i miejscach porzucenia”), „nasłuchujące otoczenie” fortepiany, które rejestrowały odgłosy miasta, przesyłane następnie do Sali Kameralnej Filharmonii Łódzkiej (stanowiącej salę odsłuchową) ${ }^{71}$. Powstał w ten

67 Wypowiedź za: Jan Klata, Anna R. Burzyńska, Kapitalistyczne imperium namiętności, [wywiad z Janem Klatą], „Tygodnik Powszechny” (17 września 2009), https://e-teatr.pl/kapitalistyczne-imperium-namietnosci-a77522 (dostęp: 11.09.2016).

68 Jędrzej Słodkowski, Jakub Wiewiórski, Festiwal Dialogu Czterech Kultur. Polityka bez kultury, „Gazeta Wyborcza - Łódź” (18 maja 2010), http://lodz.wyborcza.pl/ lodz/1,35136,7896488,Festiwal_Dialogu_Czterech_Kultur_Polityka_bez_kultury. html (dostęp: 15.07.2016).

69 Monika Wasilewska, Jana Klaty „Ziemia pożądana”, „Gazeta Wyborcza - Łódź” (12 września 2009), https://e-teatr.pl/jana-klaty-ziemia-pozadana-a77225 (dostęp: 10.10.2016).

70 Łukasz Drewniak, Żądza pieniądza, „Przekrój” 2009, nr 37, https://e-teatr.pl/ Zadza-pieniadza-a77556 (dostęp: 10.10.2016).

71 Projekt operowy Georga Nussbaumera, Filharmonia Łódzka im. Artura Rubinsteina, https://filharmonia.lodz.pl/pl/wydarzenia/projekt-operowy-georga-nussbaumera (dostęp: 20.10.2016). 
sposób muzyczny portret Łodzi, zwieńczony pieśniami wykonanymi przez Christinę Ascher (kontralt). Nieoczekiwanym zdarzeniem projektu okazało się zniknięcie czterech, spośród sześciu, ustawionych w mieście fortepianów, które zostały skradzione... Wprawdzie kompozytor potraktował taki obrót spraw jako ciekawą dalszą część projektu, ale dla interpretacji zagadnienia łódzkich terytoriów i miejsc zdegradowanych kradzież ta nabierała gorzkich znaczeń.

Organizacja VIII Dialogu zbiegła się z obchodami 65. rocznicy likwidacji Litzmannstadt Ghetto i 70-leciem wybuchu II wojny światowej, stąd jeden z ważnych nurtów programu - w ramach jego przestrzennej „strefy wojennej” - poświęcono wojennej historii miast. Wstrząsającym wydarzeniem artystycznym był pokazany w tym nurcie spektakl monachijskiego Kammerspiele Rechnitz (Der Würgeengel) [Rechnitz (Anioł Zagłady)]. Tekst napisała w 2008 roku noblistka Elfriede Jelinek - dla wybitnego reżysera Jossiego Wielera. Dramat oparty został na motywach autentycznego zdarzenia: zastrzelenia w nocy z 24 na 25 marca 1945 roku, podczas obchodów tzw. Gefolgschaftsfest (święta drużyny) na zamku w Rechnitz w austriackim Burgenlandzie, około dwustu węgierskich Żydów. Mordu na więźniach - niezdolnych do pracy robotnikach przymusowych - dokonano w czasie przyjęcia zorganizowanego dla nazistowskiej socjety i lokalnych zwolenników ich ideologii. Sprawcy przemilczanej zbrodni nie zostali nigdy ujęci ani osądzeni, ciał ofiar nie odnaleziono, świadkowie zniknęli. Aktorzy Münchner Kammerspiele, jak pisała Monika Wasilewska:

[... ] przez dwie godziny bombardują widzów tekstem, a jednak z sadystyczną satysfakcją nie opowiadają tej historii, po którą wszyscy przyszli. Spektakl jest właśnie o tym, jak bardzo tej zbrodni nie można opowiedzieć. [...] Bo jego tematem nie jest zbrodnia, tylko mówienie o niej - jej zaga dy wa nie. Jelinek, a za nią Wieler, pokazują mówienie, które jest milczeniem, mówienie, które niczego nie wyjaśnia. Pokazują, w jaki sposób historia staje się narracją 22 .

Publiczności 8. FD4K spektakl nie mógł nie przypomnieć zbrodni w Jedwabnem, która wyznacza polskie przemilczane „terytoria” pamięci. Także wystawa fotografii Piotra Piluka: Pamięć o Holokauście $w$ przestrzeniach miejskich. Berlin-Łódź-Warszawa-Lwów uwidaczniała: „[... ] paradoks pokazania niewyobrażalnego. Zobrazowania pustki"73. Kontekstem dla spektaklu i wy-

72 Monika Wasilewska, Niemcy pępkiem świata, „Gazeta Wyborcza - Łódź” (14 września 2009), https://e-teatr.pl/niemcy-pepkiem-swiata-a77253 (dostęp: 20.10.2016).

73 Jakub Papuczys, Festiwal Dialog Czterech Kultur. Odsłona trzecia, „Nowa Siła Krytyczna” (10 września 2009), https://e-teatr.pl/festiwal-dialog-czterech-kulturodslona-trzecia-a77138 (dostęp: 20.09.2016). 
stawy stał się projekt: Zobaczyć Gorgonę. Holokaust, nazizm a problem obrazowania, skupiony wokół książki Obrazy mimo wszystko, wybitnego teoretyka obrazu - Georgesa Didi-Hubermana. Projekt dotyczył zagadnienia estetycznej i etycznej (nie)możliwości/dopuszczalności tworzenia wizualnych reprezentacji Holokaustu i obejmował wykłady: Didi-Hubermana (Obraz-fetysz), amerykańskiego filmoznawcy Stuarta Liebmana (Obraz obozu) oraz panel dyskusyjny Obraz-montaż, obraz-archiwum, w którym - obok zaproszonych wykładowców - wzięli udział polscy naukowcy: Tomasz Majewski, Paweł Mościcki, Anna Zeidler-Janiszewska. W ramach projektu pokazane zostały także filmowe obrazy Zagłady w wyborze zaproponowanym przez Tomasza Majewskiego, jak również odbyła się promocja książki Pamięć Shoah. Kulturowe reprezentacje i praktyki upamiętniania [red. nauk. Tomasz Majewski i Anna Zeidler-Janiszewska, współpraca red. Maja Wójcik, Wydawnictwo Officyna, Łódź 2009]. „Wojenną” strefę przestrzenną VIII Festiwalu wzbogacił także przegląd filmów izraelskiego reżysera Ariego Folmana (m.in. Walc z Baszirem, 2008) i poświęcona jego twórczości dyskusja. W ramach obchodów 65. Rocznicy Likwidacji przez Niemców Litzmannstadt Ghetto w Łodzi, na scenie w Manufakturze zorganizowano niekonwencjonalny koncert, $\mathrm{w}$ którym wystąpiła słynna romska orkiestra dęta z macedońskiego miasta Kočani - Kočani Orkestar oraz liderzy izraelskiej muzyki z Tel Awiwu - zespół Boom Pam.

Natomiast w obszarze „wolnej strefy” VIII Dialogu, dotyczącej tematu rewolucji i wyzwolenia, wystąpił Narodowy Stary Teatr im. Heleny Modrzejewskiej w Krakowie, prezentując „zbiorową fantazję inspirowaną twórczością Andy’ego Warhola”, czyli Factory 2 Krystiana Lupy. Siedmiogodzinny spektakl przyniósł głęboki namysł nad znaczeniem kategorii Terytorium. Przedstawienie stanowiło, jak pisał Jakub Papuczys:

[...] doskonałą i żywą definicją terminu Terytorium. Krystianowi Lupie udało się hasło festiwalu zintensyfikować do jednego miejsca. Uczynić salę teatralną miejscem rozważań nad jego znaczeniami. Pozwolić poczuć widzom, czym może ono być, jak możemy je sami zdefiniować. Łódzki pokaz spektaklu rozszerza wieloznaczność tego terminu i świetnie wpisuje się w kontekst całego festiwalu ${ }^{74}$.

Tak pogłębiona interpretacja festiwalowego hasła „Terytorium”, z jaką publiczność spotkała się w interpretacji Lupy, wskazywała też na sposób kształtowania nowej odsłony Festiwalu. Organizatorzy nie pragnęli schlebiać publiczności,

74 Jakub Papuczys, Festiwal Dialog Czterech Kultur. Odsłona druga, Nowa Siła Krytyczna, https://e-teatr.pl/festiwal-dialogu-czterech-kultur-odslona-druga-a77136 (dostęp: 20.09.2016). 
bawić jej ludycznymi imprezami czy skłaniać do sentymentalnych wzruszeń. Podkreślając wielokulturowy charakter dziedzictwa Łodzi, pragnęli wykorzystać to, co minione, na potrzeby teraźniejszości, czyli wskazać konieczność budowania własnej genealogii i tożsamości mieszkańców miasta; także tożsamości dzisiejszych Europejczyków, świadomych zasad poszanowania innych kultur i czerpania z ich dorobku. Służyły temu celowi wydarzenia artystyczne i poświęcona im refleksja, budowana w czasie spotkań, dyskusji, konferencji, ale także prezentowana $\mathrm{w}$ formie tekstów drukowanych w katalogach festiwalowych (specjalne wypowiedzi przygotowywały autorytety współczesnej kultury, m.in. Zygmunt Bauman). Jak konstatował Niziołek: „Dbaliśmy o to, żeby nasza propozycja była komunikatywna, a zarazem na wysokim artystycznym poziomie. Chcemy stawiać publiczności wyzwania, ale nie wykluczać nikogo z kręgu odbiorców. [...] Zależało nam na dramaturgii wydarzeń. Festiwal musi być całością"75.

Niestety FD4K w roku 2010 dotychczasowi organizatorzy odwołali, co było wynikiem narastającego konfliktu między Miastem Dialogu a władzami Łodzi ${ }^{76}$. Przyglądanie się charakterowi i przemianom tego konfliktu nie jest moim zamiarem - został on już zresztą wyczerpująco opisany ${ }^{77}$. Jako swoista kontynuacja idei Witolda Knychalskiego, w tym samym roku 2010, powołany został Festiwal Łódź Czterech Kultur. Jego organizatorem jest Centrum Dialogu im. Marka Edelmana w Łodzi. W czasie trzech pierwszych edycji nowego festiwalu zachowano jego tematyczne sprofilowanie (2010 - „Powroty”, 2011 - „Mistrzowie”, 2012 - „Generacje”). Od roku 2012 do czerwca 2016 roku dyrektorem artystycznym Festiwalu był Zbigniew Brzoza ${ }^{78}$.

Powstanie i rozwój FD4K oraz znaczenie, jakie przypisywano temu wydarzeniu, nie osiągnęlyby, jak sądzę, takiej dynamiki, gdyby nie wpisanie imprezy - nie tylko w deklaracjach jej organizatorów, lecz przede wszystkim w szerokiej, ogólnokulturowej perspektywie - w kilka istotnych debat społecznych początków XXI wieku, skupionych wokół zagadnień wieloetniczności i multikulturalizmu.

75 Grzegorz Niziołek, Krzysztof Kowalewicz, Łódź - laboratorium przemian [wywiad z Grzegorzem Niziołkiem], „Gazeta Wyborcza - Łódź” (20 czerwca 2008), https://e-teatr.pl/Lodz-niziolek-o-dialogu-czterech-kultur-a55874 (dostęp: 20.10.2016).

76 Łukasz Biskupski, Tomasz Majewski, Festiwal Dialogu ...

77 Zob.: np.: Jędrzej Słodkowski, Jakub Wiewiórski, Festiwal Dialogu ...; Anna Pawłowska, Łódź - miasto festiwali...

78 Strona internetowa Festiwalu: http://www.4kultury.pl/. Por. też: Zbigniew Brzoza, Łukasz Kaczyński, Jestem dumny, że trudniej będzie todzianom wcisnać tandetę i szmirę, „Dziennik Łódzki” (19 czerwca 2016), http://www.dzienniklodzki.pl/opinie/ wywiady/a/zbigniew-brzoza-jestem-dumny-ze-trudniej-bedzie-lodzianom-wcisnac-tandete-i-szmire-rozmowa,10122554/ (dostęp: 20.07.2016). 
A także - gdyby nie włączenie Festiwalu w żywo zajmującą uwagę dzisiejszej humanistyki problematykę performatywnych wymiarów dyskursów historii, pamięci i tożsamości. Jak piszą Biskupski i Majewski:

Wartość Festiwalu Dialogu Czterech Kultur polegała na tym, że w swojej stosunkowo krótkiej historii dopracował się on formuly, która pozwalała przenieść lokalne problemy miasta, kwestię jego indywidualnej pamięci w pole zuniwersalizowanego języka sztuki. Interdyscyplinarny charakter sprawił, że podczas ostatnich dwóch edycji, przeistoczył się on z „eventowej” produkcji w platformę praktyk artystycznych, refleksji socjologicznej i kulturoznawczej. Niebagatelne znaczenie miało zainicjowanie procesu wyłaniania się nowego dyskursu tożsamości Łodzi, który w ciągu kilku lat przyniósł konsekwencje w wymiarze psychologii miasta, reprezentacji społecznych, odcisnął się na wizerunku międzynarodowym Łodzi i przyczynił do jego promocji ${ }^{79}$.

Wydaje się, że sens pomysłu, który decydował o sile Festiwalu Dialogu Czterech Kultur (w jego najlepszych odsłonach) polegał na próbie wydobywania z tkanki miasta i redefinicji w świadomości współczesnych łodzian rzeczywistego znaczenia i specyfiki miejsca, w którym żyją, oraz uczynienia z tego wizerunku Miasta przestrzeni odniesienia dla odkrywania/budowania tożsamości - swojej i Łodzi. Problem jednak w tym, że wieloetniczna kultura miasta to jego przeszłość; dzisiejsza społeczność Łodzi zazwyczaj nie tylko nie zna realiów tej przeszłości, ale - zajęta doraźnymi próbami przeciwdziałania procesom ubożenia miasta - zdaje się nie doceniać tkwiącego w nim potencjału. Charakterystyczne jest, że to przybysze silniej dostrzegają walory Łodzi niż jej mieszkańcy. Jak podkreślała Agata Siwiak: „[...] to miasto nieprawdopodobnych kontrastów, o genialnej architekturze, które ma w sobie jeszcze mnóstwo pytań i którego historia jest wyjątkowo odczuwalna, pulsująca. Nie przez przypadek tu narodziła się awangarda w sztuce. Do tego trzeba wrócić. Do miasta, które rewolucjonizuje" 80 .

Praca nad przywróceniem miastu jego niezakłamanej pamięci, nieprzemilczanie także mało atrakcyjnych wizerunkowo, lecz prawdziwych dziejów powstającej tu wspólnoty, daje dzisiejszym odbiorcom szansę, by doświadczyli jej charakteru. Przynajmniej w tym jej kulturowym wymiarze, jaki jest w stanie stworzyć wydarzenie artystyczne. Jak napisał Andrzej Bart:

79 Łukasz Biskupski, Tomasz Majewski, Festiwal Dialogu ..., s. 55-56.

80 Agata Siwiak, Anna Pawłowska, Festiwal wierzy $w$ łodzian [wywiad z Agatą Siwiak], Polska „Dziennik Łódzki” (17 czerwca 2008), https://e-teatr.pl/Lodz-agatasiwiak-o-dialogu-czterech-kultur-a55712 (dostęp: 17.10.2016). 
Mity trzeba nieustannie przypominać i dopowiadać. Biblijne słowa „Ziemia Obiecana”, użyte przez Reymonta i powtórzone przez Wajdę, powinny obowiązywać, mimo że miasto mało może obiecać. [... ] Mit wielokulturowego miasta, w którym ludzie różnych wyznań wzajemnie się szanowali, jest teraz bardziej potrzebny Polsce niż samej Łodzi. To, że prawie każdy Niemiec słyszał o Theo, który jechał do Łodzi, że każdy nowojorski Żyd miał tu kuzyna, nie jest zasługą współczesności, ale dzięki temu właśnie współczesność ma się od czego odbić 81 .

Mam nadzieję, że nowe łódzkie wydarzenia artystyczne podejmą ideę Festiwalu Dialogu Czterech Kultur właśnie w takiej perspektywie, a Miasto kolejny raz zdobędzie się na wysiłek transformacji - zapewniający mu tak osobność, jak i trwanie.

\section{Bibliografia}

[ze względu na liczbę wykorzystanych źródeł podaję tu tylko ważniejszą bibliografię, wszystkie źródła są uwzględnione w przypisach - S.Sz.]

Bart Andrzej, Nadzieja i czekanie. Z Andrzejem Bartem rozmawia Iga Gańczarczyk, Katalog Festiwal Dialogu Czterech Kultur’09, 5-12 września 2009, koncepcja i red. Katalogu Iga Gańczarczyk, współ. Marta Michalak, Grzegorz Niziołek, Festiwal Dialogu Czterech Kultur, Łódź 2009, s. 41-46.

Biskupski Łukasz, Miasto Atrakcji. Narodziny kultury masowej na przełomie XIX i XX wieku. Kino w systemie rozrywkowym Łodzi, Narodowe Centrum Kultury, Szkoła Wyższa Psychologii Społecznej w Warszawie, Warszawa 2013, http:/ / otworzksiazke.pl/ images/ksiazki/miasto_atrakcji/miasto_atrakcji.pdf (dostęp: 20.07.2016).

Biskupski Łukasz, Majewski Tomasz, Festiwal Dialogu Czterech Kultur w Łodzi - studium przy-(u)padku, „Kultura Współczesna” 2010, nr 4, s. 45-60, http:// docplayer. pl/9433307-Festiwal-dialogu-czterech-kultur-w-lodzi-studium-przy-u-padku.html (dostęp: 20.07.2016).

Cudny Waldemar, The Role of the Dialogue of Four Cultures Festival in Preserving the Multinational and Multicultural Heritage of Lodz, Centre for Tourism \& Cultural Change, Leeds Metropolitan University, https://www.academia.edu/10183397/

81 Za: Andrzej Bart, Nadzieja i czekanie. Z Andrzejem Bartem rozmawia Iga Gańczarczyk, Katalog Festiwal Dialogu Czterech Kultur’09, 5-12 września 2009, koncepcja i red. Katalogu Iga Gańczarczyk, współ. Marta Michalak, Grzegorz Niziołek, Festiwal Dialogu Czterech Kultur, Łódź 2009, s. 45. Wikipedia Wolna encyklopedia online: https:// pl.wikipedia.org/wiki/Theo_wir_fahr\%27n_nach_Lodz (dostęp: 20.10.2016). 
Cudny_W_2007_The_Role_of_the_Dialogue_of_Four_Cultures_Festival_in Preserving_the_Multinational_and_Multicultural_Heritage_of_L̄odz_Conf. Proceedings_Journeys_of_Expression_VI_Diaspora_Community_Festivals_ and_Tourism_Published_by_the_Centre_for_Tourism_and_Cultural_Change_Leeds_Metropolitan_Üniversity (dostęp: 28.11.2016).

Czerniak Anna, Pawlikowska Magdalena, Festiwal Dialogu Czterech Kultur jako sposób na promocję wielokulturowości Łodzi, [w:] Innowacje i doradztwo w gospodarce przestrzennej, red. Barbara Manikowska, „Zeszyty Naukowe Studenckiego Koła Naukowego Gospodarki Przestrzennej Uniwersytetu Ekonomicznego w Poznaniu”, Wydawnictwo AT Group, Poznań 2011, s. 87-97.

Dinter Henryk Stanisław, Dzieje wielkiej kariery. Łódź 1332-1860, Wydawnictwo Łódzkie, Łódź 1968.

Jakóbczyk-Gryszkiewicz Jolanta, Łódź u progu XXI wieku, „Studia Miejskie” 2011, t. 4, s. 131-138.

Koter Marek, Kulesza Mariusz, Puś Wiesław, Pytlas Stefan, Wptyw wielonarodowego dziedzictwa kulturowego Łodzi na wspólczesne oblicze miasta, Wydawnictwo Uniwersytetu Łódzkiego, Łódź 2005.

Kwaśniewska Monika, ... nienawiść, pogarda, bunt, śmierć..., „Didaskalia” 2008, nr 87, s. 7-9, http://www.didaskalia.pl/87 kwasniewska.htm (dostęp: 20.10.2016).

Leyko Małgorzata, Miasto przyglada się festiwalom, [w:] Między świętem a przesytem. Festiwale teatralne i ich miejsce we współczesnym życiu kulturalnym Polski, red. Dariusz Kosiński, Teatr Lalek „Pleciuga”, Szczecin 2016, s. 93-99.

Łódź. Dzieje Miasta. T 1. Do 1918 r., red. Bohdan Baranowski, Jan Fijałek, Państwowe Wydawnictwo Naukowe, Warszawa-Łódź 1980.

Majcherek Janusz A., Mit wielokulturowości jako ideat aksjologiczny, [w:] Etniczność - o przemianach społeczeństw narodowych, red. Maria Szmeja, Zakład Wydawniczy Nomos, Kraków 2008, s. 193-202.

Strona internetowa designteka.pl, Wydarzenia.,Anabasis. Rytuaty powrotu do domu, http:// designteka.pl/anabasis-rytualy-powrotu-do-domu.html (dostęp: 20.10.2016).

Strona internetowa Festiwalu Dialogu Czterech Kultur, http://www.4kultury.pl/ (dostęp: 20.10.2016). 